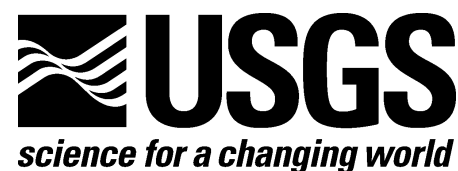

Toxic Hydrology Program

\title{
Results of the Chemical and Isotopic Analyses of Sediment and Ground Water from Alluvium of the Canadian River Near a Closed Municipal Landfill, Norman, Oklahoma, Part 2
}

By George N. Breit, Michele L.W. Tuttle, Isabelle M. Cozzarelli, Cyrus J. Berry, Scott C. Christenson, and Jeanne B. Jaeschke

Open-File Report 2008-1134 


\section{U.S. Department of the Interior \\ DIRK KEMPTHORNE, Secretary}

\section{U.S. Geological Survey \\ Mark D. Myers, Director}

\section{U.S. Geological Survey, Denver, Colorado 2008}

For product and ordering information:

World Wide Web: http://www.usgs.gov/pubprod

Telephone: 1-888-ASK-USGS

For more information on the USGS - the Federal source for science about the Earth, its natural and living resources, natural hazards, and the environment:

World Wide Web: http://www.usgs.gov

Telephone: 1-888-ASK-USGS

Suggested citation:

Breit, G.N., Tuttle, M.L.W., Cozzarelli, I.M., Berry, C.J., Christenson, S.C. and Jaeschke, J.B., 2008, Results of the chemical and isotopic analyses of sediment and ground water from alluvium of the Canadian River near a closed municipal landfill, Norman, Oklahoma, Part 2: U.S. Geological Survey Open-file Report 2008-1134, 35 p.

Open-File Reports are used for the dissemination of information that must be released immediately to fill a public need or for information that is not sufficiently refined to warrant formal publication. As such, Open-File Reports should not be viewed as final reports of major scientific investigations. Because of their preliminary nature and possibility of being superseded open-file reports do not introduce new or revise geologic, stratigraphic, hydrologic or taxonomic nomenclature. In particular, Article 4(a) of the North American Stratigraphic Code excludes, Open-file releases for the naming or revising of formal geologic units. Use of brand names is intended for descriptive purposes only and does not represent an endorsement by the U.S. Geological Survey. Any use of trade, product, or firm names is for descriptive purposes only and does not imply endorsement by the U.S. Government. 


\section{Contents}

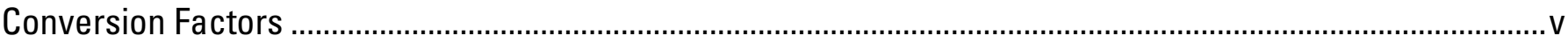

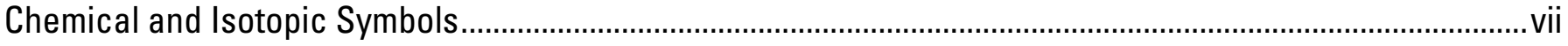

Abstract

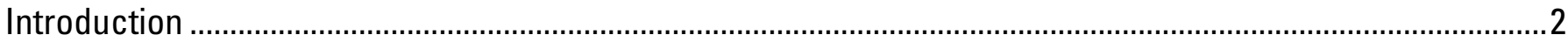

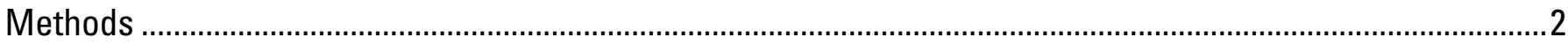

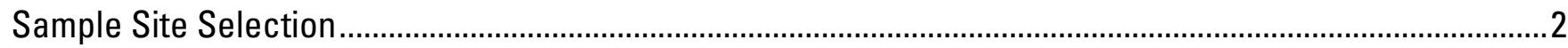

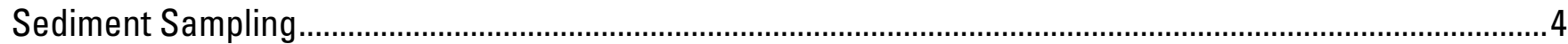

Water Sampling and Field Analyses .........................................................................................................

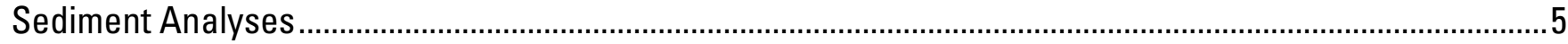

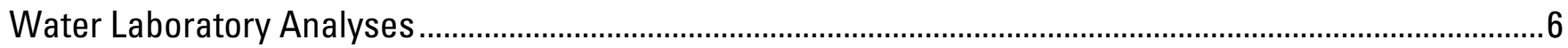

Results

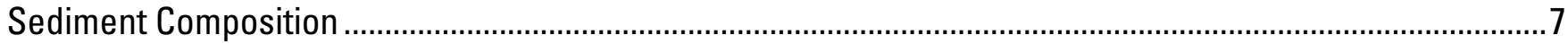

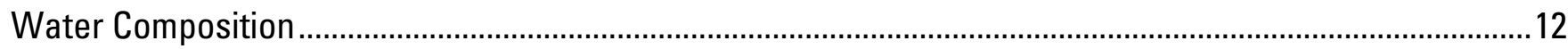

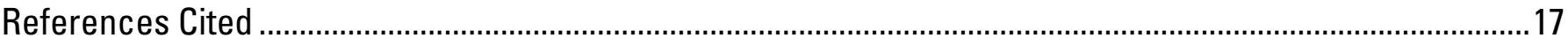

\section{Figures}

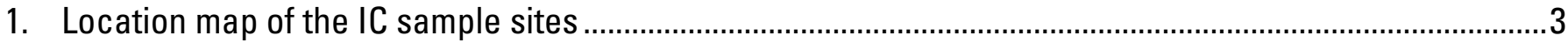

2. Cumulative abundance of size fractions measured by sieve analysis of sediment samples collected at IC 35, IC 54, and IC South.

3. Depth variation in total iron concentration extracted using $0.5 \mathrm{~N} \mathrm{HCl}$ and $\mathrm{Ti}^{3+}$-EDTA on sediment samples collected at IC 36, IC 54, and IC South.

4. Depth variation in the ratio of ferrous to total iron extracted with $0.5 \mathrm{~N} \mathrm{HCl}$ from sediment samples collected at IC 36, IC 54, and IC South

5. Abundance of iron extracted from sediment samples with $T^{3+}{ }^{3+}$ EDTA relative to the abundance of particles smaller than $100 \mu \mathrm{m}$

6. Depth variation in the abundance of acid-volatile sulfide and disulfide extracted from the sediment samples collected at IC 36, IC 54, and IC South.

7. Box plot of the sulfur isotope composition of sulfur species extracted from the sediment samples collected at IC 36 , IC 54 and IC South....

8. Depth variation of chloride concentration of ground water from the wells at IC 36, IC 54, and IC South in October 2004 and April 2005.

9. Depth variation of iron concentration of ground water from the wells at IC 36, IC 54, and IC South in October 2004 and April 2005 
10. Depth variation of sulfate concentration of ground water from the wells at IC 36 , IC 54 , and IC South in October 2004 and April 2005

11. Piper diagram of major ion composition of ground water samples from wells at IC 36 , IC 54, and IC South

\section{Tables}

1. Location of sample sites 3

2. Summary statistics of water composition from IC 36, IC 54, and IC South 13

\section{Appendices}

1. Depth intervals of the wells sampled at IC 36 , IC 54 , and IC South 19

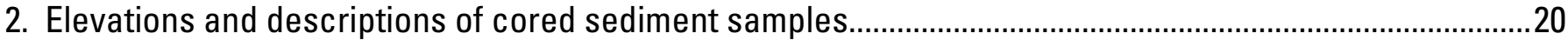

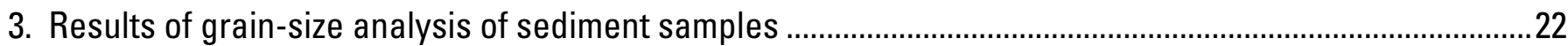

4. Concentration of iron sequentially extracted from sediment samples using $0.5 \mathrm{~N} \mathrm{HCl}$ and $\mathrm{Ti}^{3+}$-EDTA ......24

5. Concentrations of sulfur species in sediment samples and their sulfur isotopic composition ....................26

6. Results of chemical and isotopic analyses of ground water samples from wells at IC 36, IC 54, and IC South 


\section{Conversion Factors}

Inch/Pound to SI

\begin{tabular}{lcl}
\hline \multicolumn{1}{c}{ Multiply } & \multicolumn{1}{c}{ By } & \multicolumn{1}{c}{ To obtain } \\
\hline Length & & \\
\hline inch (in.) & 2.54 & centimeter (cm) \\
inch (in.) & 25.4 & millimeter (mm) \\
foot (ft) & 0.3048 & meter (m) \\
mile (mi) & 1.609 & kilometer (km) \\
mile, nautical (nmi) & 1.852 & kilometer (km) \\
yard (yd) & 0.9144 & meter (m) \\
\hline Volume & & \\
\hline ounce, fluid (fl. oz) & 0.02957 & liter (L) \\
pint (pt) & 0.4732 & liter (L) \\
quart (qt) & 0.9464 & liter (L) \\
gallon (gal) & 3.785 & liter (L) \\
cubic inch (in $\left.{ }^{3}\right)$ & 0.01639 & liter (L) \\
\hline Mass & & \\
\hline ounce, avoirdupois (oz) & 28.35 & gram (g) \\
pound, avoirdupois (lb) & 0.4536 & kilogram (kg) \\
& &
\end{tabular}

Temperature in degrees Celsius $\left({ }^{\circ} \mathrm{C}\right)$ may be converted to degrees Fahrenheit $\left({ }^{\circ} \mathrm{F}\right)$ as follows: ${ }^{\circ} \mathrm{F}=\left(1.8 \mathrm{x}^{\circ} \mathrm{C}\right)+32$

Temperature in degrees Fahrenheit $\left({ }^{\circ} \mathrm{F}\right)$ may be converted to degrees Celsius $\left({ }^{\circ} \mathrm{C}\right)$ as follows: ${ }^{\circ} \mathrm{C}=\left({ }^{\circ} \mathrm{F}-32\right) / 1.8$

Vertical coordinate information is referenced to the North American Vertical Datum of 1988 (NAVD 88).

Horizontal coordinate information is referenced to the North American Datum of 1983 (NAD 83).

Elevation, as used in this report, refers to distance above the vertical datum. 


\section{SI to Inch/Pound}

\begin{tabular}{lll}
\hline \multicolumn{1}{c}{ Multiply } & \multicolumn{1}{c}{ By } & \multicolumn{1}{c}{ To obtain } \\
\hline Length & & \\
\hline centimeter $(\mathrm{cm})$ & 0.3937 & inch (in.) \\
millimeter $(\mathrm{mm})$ & 0.03937 & inch (in.) \\
meter $(\mathrm{m})$ & 3.281 & foot (ft) \\
meter $(\mathrm{m})$ & 1.094 & yard (yd) \\
\hline Volume & & \\
\hline liter $(\mathrm{L})$ & 33.82 & ounce, fluid (fl. oz) \\
liter (L) & 2.113 & pint (pt) \\
liter (L) & 1.057 & quart (qt) \\
liter (L) & 0.2642 & gallon (gal) \\
cubic meter $\left(\mathrm{m}^{3}\right)$ & 264.2 & gallon (gal) \\
cubic decimeter $\left(\mathrm{dm}^{3}\right)$ & 0.2642 & gallon (gal) \\
liter (L) & 61.02 & cubic inch (in $\left.{ }^{3}\right)$ \\
\hline Mass & & \\
\hline gram (g) & 0.03527 & ounce, avoirdupois (oz) \\
kilogram $(\mathrm{kg})$ & 2.205 & pound avoirdupois (lb) \\
& &
\end{tabular}

Abbreviated Units Chemical concentration and water temperature are given only in metric units. Chemical concentration in water is given as milligrams per liter ( $\mathrm{mg} / \mathrm{L})$. Chemical concentrations in solid phase samples are given as micromoles per gram ( $\mu$ moles $\left.\mathrm{g}^{-1}\right)$. Grain size abundances are listed in weight percent (wt.\%). Specific conductance is given in microsiemens per centimeter at 25 degrees Celsius $\left(\mu \mathrm{S} / \mathrm{cm}\right.$ at $\left.25^{\circ} \mathrm{C}\right)$. Stable-isotope ratios are reported relative to internationally agreed-upon standards. Deviations from standards are expressed in per mil using the delta $(\delta)$ notation. The delta symbol in this report is followed by the chemical symbol for the heavier isotope measured during isotopic analysis. 


\section{Chemical and Isotopic Symbols}

\begin{tabular}{|c|c|}
\hline $\mathrm{Ag}_{2} \mathrm{~S}$ & silver sulfide \\
\hline AVS & acid-volatile sulfide \\
\hline $\mathrm{BaCl}_{2}$ & barium chloride \\
\hline $\mathrm{BaSO}_{4}$ & barium sulfate \\
\hline $\mathrm{Ca}$ & calcium \\
\hline $\mathrm{Cl}^{-}$ & chloride \\
\hline DI & disulfide sulfur \\
\hline EDTA & ethylenediaminetetraacetic acid \\
\hline $\mathrm{Fe}$ & iron \\
\hline $\mathrm{Fe}^{2+}$ & ferrous iron \\
\hline $\mathrm{FeS}_{2}$ & iron disulfide \\
\hline $\mathrm{Fe}_{\text {total }}$ & sum of ferrous and ferric iron \\
\hline $\mathrm{HCl}$ & hydrochloric acid \\
\hline $\mathrm{HCO}_{3}^{-}$ & bicarbonate ion \\
\hline $\mathrm{H}_{2} \mathrm{~S}$ & hydrogen sulfide \\
\hline $\mathrm{K}$ & potassium \\
\hline $\mathrm{Mg}$ & magnesium \\
\hline $\mathrm{N}$ & normal (concentration) \\
\hline $\mathrm{Na}$ & sodium \\
\hline $\mathrm{NH}_{4}^{+}$ & ammonium \\
\hline $\mathrm{S}$ & sulfur \\
\hline $\mathrm{SO}_{4}^{2-}$ & sulfate \\
\hline $\mathrm{Ti}$ & titanium \\
\hline$\delta^{2} \mathrm{H}_{\mathrm{H} 2 \mathrm{O}}$ & hydrogen isotope composition of water \\
\hline$\delta^{18} \mathrm{O}_{\mathrm{H} 2 \mathrm{O}}$ & oxygen isotope composition of water \\
\hline$\delta^{18} \mathrm{O}_{\mathrm{sO} 4}$ & oxygen isotope composition of sulfate \\
\hline$\delta^{34} \mathrm{~S}_{\mathrm{AVS}}$ & sulfur isotope composition of acid-volatile sulfide \\
\hline$\delta^{34} S_{\mathrm{DI}}$ & sulfur isotope composition of disulfide (reducible) sulfur \\
\hline sulfate- $\mathrm{HCl}$ & sulfur isotope composition of sulfate extracted with $6 \mathrm{~N} \mathrm{HCl}$ \\
\hline
\end{tabular}




\title{
Results of the Chemical and Isotopic Analyses of Sediment and Ground Water from Alluvium of the Canadian River Near a Closed Municipal Landfill, Norman, Oklahoma, Part 2
}

By George N. Breit, Michele L.W. Tuttle, Isabelle M. Cozzarelli, Cyrus J. Berry, Scott C. Christenson, and Jeanne B. Jaeschke

\begin{abstract}
Analytical results on sediment and associated ground water from the Canadian River alluvium collected subsequent to those described in Breit and others (2005) are presented in this report. The data presented herein were collected primarily to evaluate the iron and sulfur species within the sediment at well sites IC 36, IC 54, and IC South located at the USGS Norman Landfill study site. Cored sediment and water samples were collected during October 2004 and April 2005. The 52 sediment samples collected by coring were analyzed to determine grain size, the abundance of extractable iron species, and the abundance of sulfur forms and their isotopic compositions. Ground water was collected from cluster wells that sampled ground water from 11 to 15 screened intervals at each of the three sites. The depth range of the wells overlapped the interval of cored sediment. Concentrations of major ions, dissolved organic carbon (DOC), ammonium, and iron are reported with $\mathrm{pH}$, specific conductance, and the isotopic composition of the water for the 75 water samples analyzed. Dissolved sulfate in selected water samples was analyzed to determine its sulfur and oxygen isotope composition.
\end{abstract}

\section{Introduction}

Landfills were sited adjacent to rivers prior to the passage of regulations intended to restrict the impact of solid wastes and leachates produced by interaction of ground and surface water with those wastes (Steiner and others, 1994). The U.S. Geological Survey (USGS) Toxic Hydrology Program is supporting the study of a closed municipal landfill located on Canadian River alluvium south of the city of Norman, Oklahoma, to evaluate the environmental impact of one of these waste repositories. The closed Norman municipal landfill operated in varying forms beginning in the 1920s until 1985 (fig. 1) (Schlottmann, 2001). Initially the wastes were dispersed along the north bank of the river. Beginning in 1960, the operators excavated trenches to the water table and buried wastes beneath $15 \mathrm{~cm}$ of sand. Trenches were abandoned in 1971, and wastes were deposited on lifts of sand 0.6 meters above the water table. Wastes were buried daily with sand. The landfill was closed in 1985 and covered with a low-permeability cap, leaving two mounds rising about 12 meters above the surrounding land surface (Schlottmann, 2001). 
Movement of ground water through the waste produces a leachate distinguished by high concentrations of several dissolved constituents including organic carbon, iron, methane, ammonium, and boron (Cozzarelli and others, 2000; Schlottmann, 2001). Chemical and biological processes that degrade organic contaminants as the leachate moves through the Canadian River alluvium are the primary emphasis of the project. Collectively these attenuation processes may be important as a means of natural remediation. Bacterial oxidation of the contaminant organic compounds is supported by the presence of electron acceptors such as dissolved oxygen, nitrate, and sulfate, as well as solid manganese and ferric oxyhydroxides and oxides. This report presents data on the abundance of solid forms of iron and sulfur species in sediment within 2.8 meters of the ground surface as an addition to the previously published results of Breit and others (2005). In addition, ground water proximal to the sediment samples was chemically and isotopically analyzed. The depth range evaluated in this study is subject to seasonal fluctuations in water level (Becker, 2002; Scholl and others, 2005), with the shallowest ground water originating largely from infiltration of precipitation into the sediment (Scholl and others, 2005; 2006). The annual changes in water level are anticipated to affect the redox environment of the sediment and therefore the abundance of electron acceptors. A greater abundance of reduced forms of iron and sulfur are predicted following high water levels that are characteristic of spring, and the converse behavior is anticipated in the fall because of low water levels in late summer (Scholl and others, 2006). Such an annual fluctuation may impact the availability of electron acceptors necessary for natural attenuation processes. To test this hypothesis, samples of sediment and ground water were collected in October 2004 and April 2005 to represent seasons of generally low and generally high water levels, respectively. Results of sediment and water analyses are presented in this report.

\section{Methods}

\section{Sample Site Selection}

Previous studies by Scholl and others $(2005,2006)$ explored the annual variations in water composition at sites of three cluster wells, IC 36, IC 54, and IC South. Because of the known variation in water composition at these sites, they were the focus of this investigation. The IC sites are south of the landfill mounds (fig. 1; table 1), which is down the hydrologic gradient (Scholl and Christenson, 1998). The locations of the sites are: IC 36, $35 \mathrm{~m}$ from the toe of the landfill mound; IC 54, $7 \mathrm{~m}$ south of the slough, which is a former channel of the Canadian River; IC South, $85 \mathrm{~m}$ south of the slough and located in an area disturbed by major floods and channel avulsion during the 1980s (Schlottmann, 2001).

Variations in the chemical and isotopic composition of water recovered from the IC sites reflect the distinct histories of water collected at the various sampled depths and locations (Scholl and others, 2005; 2006). All sites produced water in the shallowest intervals, which is attributed to dilute recharge by precipitation. Deeper water at IC 36 is considered to contain a component of leachate from the landfill. Water in the lower wells at IC 54 is consistent with recharge from the slough and possibly leachate. At IC South the deepest wells sampled may produce water originally recharged from the slough or from the Canadian River (Scholl and others, 2005; 2006). 
Table 1. Location of the IC sample sites and water levels at the time of sampling. Horizontal coordinates relative to NAD83 datum. Elevation relative to NADV88 datum.

\begin{tabular}{cccccc}
\hline $\begin{array}{c}\text { Sample } \\
\text { Site }\end{array}$ & Latitude & Longitude & $\begin{array}{c}\text { Land Surface } \\
\text { Elevation } \\
\text { (meters) }\end{array}$ & $\begin{array}{c}\text { Water Elevation } \\
\text { 0ctober 2004 } \\
\text { (meters) }\end{array}$ & $\begin{array}{c}\text { Water Elevation } \\
\text { April 2005 } \\
\text { (meters) }\end{array}$ \\
\hline IC 36 & $35.167496^{\circ} \mathrm{N}$ & $97.446614^{\circ} \mathrm{W}$ & 330.96 & 330.11 & 330.28 \\
IC 54 & $35.166582^{\circ} \mathrm{N}$ & $97.447231^{\circ} \mathrm{W}$ & 330.56 & 329.85 & 329.90 \\
IC South & $35.165146^{\circ} \mathrm{N}$ & $97.446614^{\circ} \mathrm{W}$ & 330.31 & 329.62 & 329.59 \\
\hline
\end{tabular}

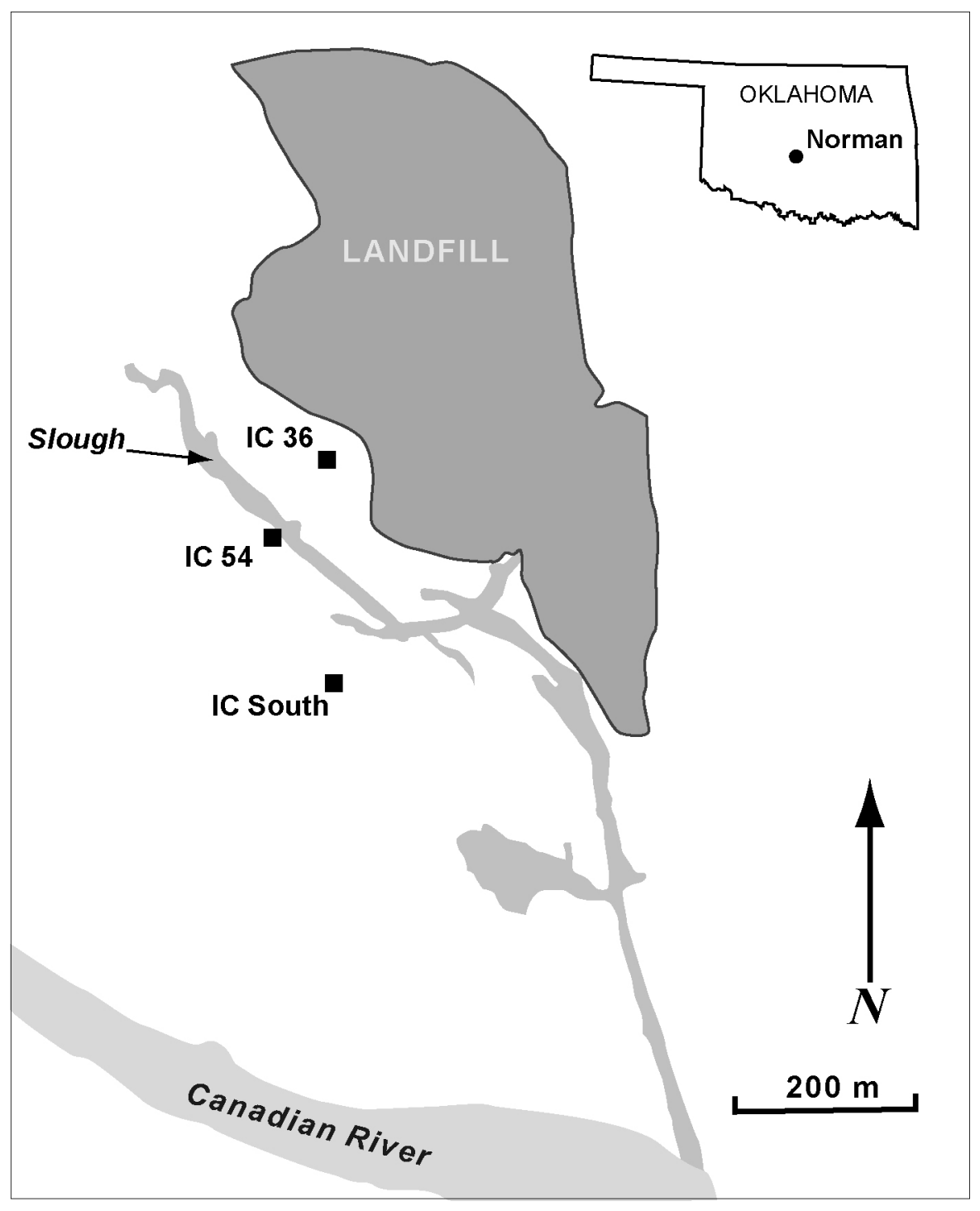

Figure 1. Location map of the IC sample sites ( $\square$ ). Topographic and hydrologic gradients slope to the south. Outline of landfill indicates the extent of the two capped landfill mounds. 


\section{Sediment Sampling}

Cores of the alluvium were recovered within a few meters laterally of the three IC cluster well sites using a Geoprobe direct-push coring device. At each of the three sites sediment was collected from the ground surface to a depth ranging from 2.1 to $2.8 \mathrm{~m}$. Recovery of the sandy sediment was incomplete in the October 2004 sampling because of problems retaining the flowing sediment in the core barrel. The missing depth range was the focus of recovery during the April 2005 core collection. During coring, sediment was captured in transparent acrylic liners that were $4.1 \mathrm{~cm}$ in diameter. The recovered core was cut into 0.1 to $0.4 \mathrm{~m}$ lengths, frozen on site with dry ice and shipped with dry ice to USGS laboratories in Denver. Upon arrival in Denver, the cores were transferred to a freezer and stored at $-10{ }^{\circ} \mathrm{C}$ to inhibit redox or microbial changes to the sediment until they were prepared for analysis.

Within one month of sample collection, the frozen core was cut into lengths that approximated the depth range of each well in the cluster. While frozen, the core was extruded and split lengthwise into four approximately equivalent fractions using a hammer and chisel. One quarter of the sample was weighed and transferred to the glass reaction vessel for sulfur speciation as described below. The second quarter was transferred to a dish and allowed to air dry for the determination of moisture content. The third quarter of each sample collected during the October 2004 collection was weighed and transferred to a polyethylene bottle for extraction of water-soluble sulfate. This extraction was omitted during analysis of the April 2005 samples. The remaining sample was allowed to thaw slightly and, while still cold, was homogenized by manual mixing. Two aliquots of the homogenized sediment were transferred to glass vials equipped with butyl rubber septa. One vial was used for the iron speciation analyses, and the other was archived after freeze-drying.

\section{Water Sampling and Field Analyses}

Water was collected from existing wells (appendix 1) following the procedures outlined by Scholl and others (2005). Water was drawn slowly from each well in the cluster using a peristaltic pump. Specific conductance and $\mathrm{pH}$ were measured on site using calibrated meters. Ammonium content was measured spectrophotometrically on unfiltered samples that were diluted to fit the reporting range of the Nessler CHEMETS kit. Water samples for determination of alkalinity were filtered to $<0.4$ micrometer $(\mu \mathrm{m})$ in the field, and transported with ice to the laboratory. An aliquot of water was filtered $(<0.1 \mu \mathrm{m})$ and acidified with high-purity concentrated nitric acid to a $\mathrm{pH}$ less than 2 for analysis of cations and trace elements in the laboratory. Another aliquot was filtered in the field to $<0.2 \mu \mathrm{m}$ and was chilled with ice and transported to the laboratory for measurement of anions. Water passed through a $0.45 \mu \mathrm{m}$ silver filter to remove bacteria and was stored in a baked glass bottle and acidified with phosphoric acid to a $\mathrm{pH}<2$ for determination of the dissolved organic carbon content. Unfiltered water was also collected in a glass bottle sealed tightly with polyseal caps to prevent evaporation and refrigerated for later determination of the hydrogen $\left(\delta^{2} \mathrm{H}\right)$ and oxygen $\left(\delta^{18} \mathrm{O}\right)$ isotope composition of the water.

\section{Sediment Analyses}

Sediment samples were analyzed to determine the grain size distribution, the abundance of extractable iron species, and the abundance and isotopic composition of extractable sulfur species. 
Stainless steel sieves were used to divide the air-dried sediment into five fractions: $>500 \mu \mathrm{m}, 500$ $250 \mu \mathrm{m}, 250-100 \mu \mathrm{m}, 100-62 \mu \mathrm{m}$, and $<62 \mu \mathrm{m}$. The sediment and sieves were shaken manually for 5 minutes and the resulting sized fractions were weighed to the nearest 0.01 gram. Although large intraclasts of mud and silt were visually recognized, they were gently disaggregated using a mortar and pestle for the size analysis. Disaggregation is compatible with the emphasis of this study on the reactivity of the sediment, which is reasonably evaluated by the dispersed particles.

Chemical extractions for iron speciation were modified slightly from those of Heron and others (1994). Approximately 5 to 10 grams of sediment was combined with $40 \mathrm{~mL}$ of 0.5 normal (N) hydrochloric acid $(\mathrm{HCl})$ in an amber glass serum vial that was purged with nitrogen gas $\left(\mathrm{N}_{2}(\mathrm{~g})\right.$ ). The sediment was reacted for 24 hours with intermittent agitation to suspend the sediment. Upon completion of the reaction, an aliquot of the $0.5 \mathrm{~N} \mathrm{HCl}$ was removed using a needle and syringe. The withdrawn solution was immediately filtered through a $0.2-\mu \mathrm{m}$ syringe filter and reacted with orthophenanthroline according to the procedure of Clesceri and others (1998) to determine ferrous and total dissolved iron concentrations. The remaining sediment was subsequently recovered by filtration, rinsed thoroughly with distilled water, and air-dried overnight.

The air-dried sediment residue of the $0.5 \mathrm{~N} \mathrm{HCl}$ was weighed and then split using a mechanical splitter into a fraction weighing between 1.5 to 3.0 grams. The weighed fraction was combined with $40 \mathrm{~mL}$ of 0.008 molar titanous chloride $\left(\mathrm{Ti}^{3+} \mathrm{Cl}_{3}\right)$ in 0.05 molar disodium ethylenediaminetetraacetic acid (EDTA) with $\mathrm{pH}$ of the combined solution adjusted to between 6 and 6.5 using sodium hydroxide. The $\mathrm{Ti}^{3+}$-EDTA solution was prepared and introduced into an amber glass serum vial under $\mathrm{N}_{2}(\mathrm{~g})$. The serum vial was sealed, purged with $\mathrm{N}_{2}(\mathrm{~g})$ for 3 minutes, wrapped with foil, and shaken intermittently over the 24 hour reaction period. Following reaction, $30 \mathrm{~mL}$ of solution was removed through the septum using a needle and syringe and then filtered through a $0.2-\mu \mathrm{m}$ syringe filter. The $\mathrm{Ti}^{3+}$-EDTA solution has a medium-intensity magenta color prior to reaction with ferric iron. This color was apparent, although less intense, at the completion of the reaction indicating that the $\mathrm{Ti}^{3+}$ was not completely consumed during reaction with the sediment. The filtered solution was then analyzed for total iron using the orthophenanthroline procedure (Clesceri and others, 1998). Although the sediment was dried in air prior to evaluation of reducible iron, the readily reactive iron phases were removed by the $0.5 \mathrm{~N} \mathrm{HCl}$ prior to air exposure, and any remaining reduced iron phases such as pyrite are slowly reactive and contribute little to the $\mathrm{Ti}^{3+}$-EDTA extraction (Heron and others, 1994).

Water-soluble sulfate was determined by combining 40 to 80 grams of cold sediment with 200 milliliters of deionized water. The sample and water were agitated for 1 hour. The resulting solution was separated from the sediment by filtration, acidified to a pH between 3 and 4 with $\mathrm{HCl}$, heated to approximately $90{ }^{\circ} \mathrm{C}$, and combined with $5 \mathrm{~mL}$ of barium chloride $\left(\mathrm{BaCl}_{2}\right)$. After several hours, the heating was discontinued, and the solution was allowed to cool overnight. The resulting barium sulfate $\left(\mathrm{BaSO}_{4}\right)$ precipitate was recovered by filtration, air-dried, and weighed.

The abundances of acid-volatile sulfide (AVS), acid-soluble sulfate, and total reducible-disulfide (DI) were determined following the extraction scheme of Tuttle and others (1986). Approximately 40 to 80 grams of frozen sediment was transferred under a nitrogen atmosphere into a glass reaction vessel. Under flowing $\mathrm{N}_{2}(\mathrm{~g})$ the sample was combined with $50 \mathrm{~mL}$ of $6 \mathrm{~N} \mathrm{HCl}$ and 1 gram of stannous chloride and heated to evolve hydrogen sulfide $\left(\mathrm{H}_{2} \mathrm{~S}\right)$ from AVS phases. The stannous chloride was added to reduce ferric iron present in hematite grain coatings that might oxidize 
evolved $\mathrm{H}_{2} \mathrm{~S}$ (Rice and others, 1993). The $\mathrm{H}_{2} \mathrm{~S}$ was then carried in flowing nitrogen through a reservoir of $\mathrm{pH} 4$ buffer to remove $\mathrm{HCl}$ vapor and subsequently bubbled through a trap containing silver nitrate, which resulted in the formation of silver sulfide $\left(\mathrm{Ag}_{2} \mathrm{~S}\right)$. The $\mathrm{Ag}_{2} \mathrm{~S}$ was collected by filtration, dried, and weighed to determine the mass of recovered sulfide.

Following completion of release of $\mathrm{H}_{2} \mathrm{~S}$, the acid solution was separated from the remaining sediment by filtration. The acid solution was reacted with $10 \mathrm{~mL}$ of 10 weight percent $\mathrm{BaCl}_{2}$ to precipitate dissolved sulfate as $\mathrm{BaSO}_{4}$, following the procedure outlined for water-extracted sulfate. The precipitated sulfate is considered acid-soluble sulfate.

The residual solid remaining after the $6 \mathrm{~N} \mathrm{HCl}$ extraction was air-dried, weighed and placed in a reaction vessel under flowing nitrogen, where it was combined with $1 \mathrm{M}$ chromous chloride $\left(\mathrm{CrCl}_{2}\right)$ in $4 \mathrm{~N} \mathrm{HCl}$ with $10 \mathrm{~mL}$ of ethanol. Chromium(II) reduces sulfur in $\mathrm{FeS}_{2}$ phases, known to be present in the sediment (Breit and others, 2005), to produce $\mathrm{H}_{2} \mathrm{~S}$. As in the AVS analysis, evolved $\mathrm{H}_{2} \mathrm{~S}$ was carried through a $\mathrm{pH} 4$ buffer to strip $\mathrm{HCl}$ vapors and then bubbled through a silver nitrate solution that precipitated the $\mathrm{H}_{2} \mathrm{~S}$ as $\mathrm{Ag}_{2} \mathrm{~S}$. The resulting $\mathrm{Ag}_{2} \mathrm{~S}$ was collected by filtration, air-dried, and weighed to determine the amount of contained disulfide sulfur. Replicate analyses produced concentrations of sulfide phases within \pm 10 weight percent.

The sulfur isotope composition of $\mathrm{Ag}_{2} \mathrm{~S}$ produced by the AVS and DI extractions, as well as the precipitated $\mathrm{BaSO}_{4}$,were measured by direct combustion (Kester and others, 2001) at the USGS Isotope Laboratory in Denver. Sulfur isotope data are reported relative to Vienna Canon Diablo Troilite (VCDT) in standard per mil values. Precision of the measurement of $\delta^{34} \mathrm{~S}$ values is within \pm 0.3 per mil.

\section{Water Laboratory Analyses}

Major ion, trace element, dissolved organic carbon, alkalinity, and isotope composition were determined on selected water samples in USGS laboratories in Reston, Virginia (Baedecker and Cozzarelli, 1992). Measurement of alkalinity was completed by tritration using a Titra Lab Tim 900 autotitrator with $0.0254 \mathrm{~N} \mathrm{HCl}$. Alkalinity is reported as bicarbonate ion (Baedecker and Cozzarelli, 1992). Direct-current plasma spectrometry determined the cation and trace element abundances in of the water samples. Anions were measured using a Dionex 120 ion chromatograph equipped with an Ion Pac AS14 column. Dissolved organic carbon (DOC) was measured by the method of Qian and Mopper (1996). Addition of dissolved barium chloride to selected water samples precipitated dissolved sulfate for isotope analyses, using the same procedure for precipitation of sulfate that was extracted by water from the sediment samples. The $\mathrm{pH}$ of the water samples was adjusted to be between 3 and 4 with addition of $\mathrm{HCl}$ to remove dissolved carbonate species while minimizing exchange of oxygen bound to sulfate. The isotopic composition of recovered sulfate and water were determined at the USGS Reston Stable Isotope Laboratory. Sulfur isotopes and oxygen isotope composition of sulfate were determined by continuous flow with precisions of \pm 0.2 and \pm 0.3 per mil respectively. Sulfate sulfur is reported relative to Vienna Canon Diablo Troilite (VCDT) and oxygen is reported relative to Vienna Standard Mean Ocean Water (VSMOW) as per mil values. The $\delta^{2} \mathrm{H}$ composition of water was determined by equilibration with gaseous hydrogen; resulting precision of this analysis was \pm 1 per mil. $\delta^{18} \mathrm{O}$ of the water was determined through equilibration with $\mathrm{CO}_{2}$; resulting precision was \pm 0.1 per mil. Both hydrogen and oxygen isotope compositions are reported as per mil relative to 
VSMOW and normalized such that the $\delta^{2} \mathrm{H}$ and $\delta^{18} \mathrm{O}$ values of Standard Light Antarctic Precipitation (SLAP) are -5.55 per mil and -4.28 per mil respectively.

\section{Results}

\section{Sediment Composition}

The alluvium deposited by the Canadian River contains sand, silt, clay, and aggregates of finegrained sediment in intraclasts (Breit and others, 2005). Most of the samples considered in this study are red-brown as the result of grain-coating hematite that was eroded from Permian red beds within the drainage basin. Exceptions to this pervasive coloration are the samples from deeper than approximately $330 \mathrm{~m}$ elevation at the IC 36 well site, which are distinguished by their gray-brown color. Bedforms observed in the IC cores vary from finely laminated to massive (appendix 2). Sedimentary structures are readily recognized in sediment collected above the water table; watersaturated sediment was likely liquefied during the coring process, resulting in disruption of primary sedimentary structures to produce the massive appearance.

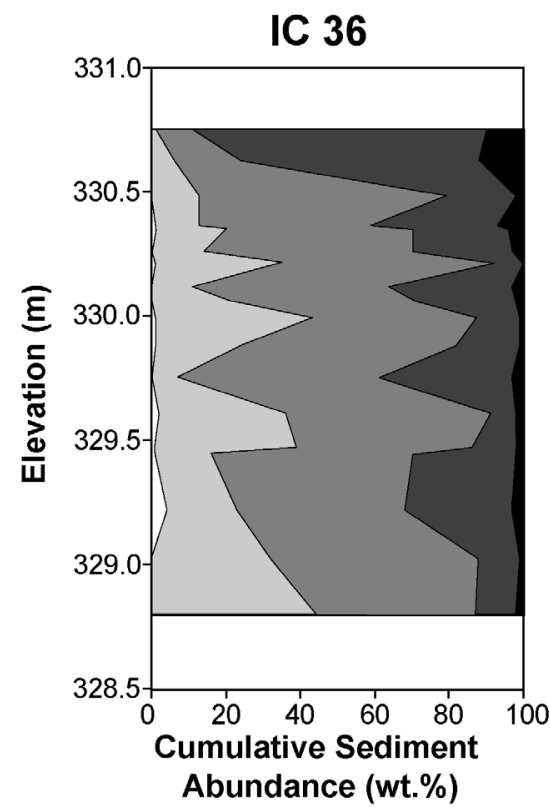

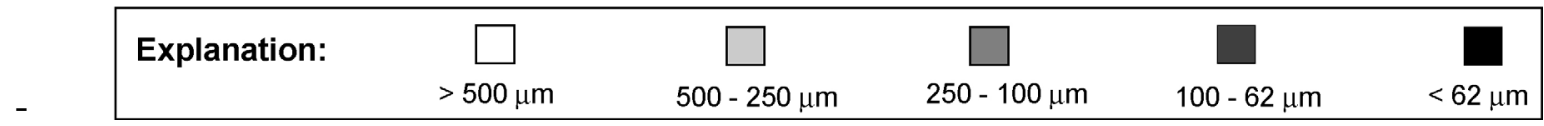

IC 54

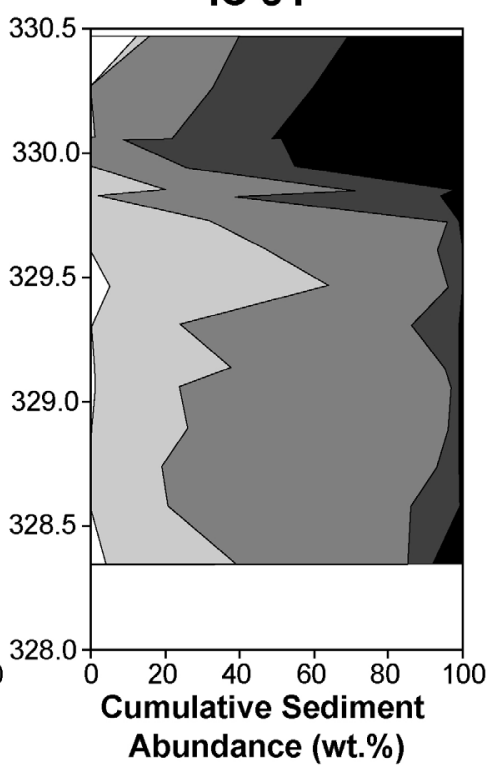

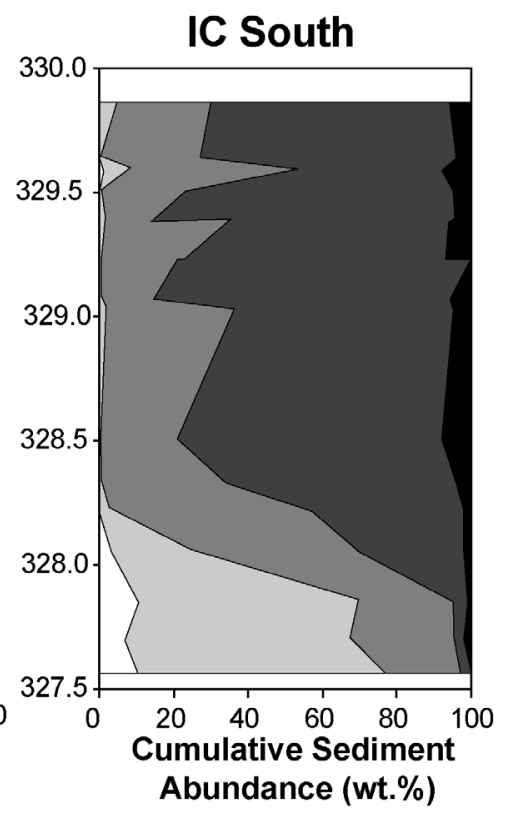

Figure 2. Cumulative abundance of size fractions measured by sieve analysis of sediment samples recovered at IC 36, IC 54, and IC South.

Results of the sieve analysis of the sediment samples are presented in figure 2 and listed in appendix 3. Sediment recovered from all cores is mainly medium to very fine sand. The deepest sediment from IC South is composed of relatively coarse-grained sediment consistent with the presence of pebble-sized intraclasts recovered in this interval. Sediment recovered from the upper 
$0.5 \mathrm{~m}$ of IC 54 is notable for the greater abundance of particles less than $62 \mu \mathrm{m}$ compared to other cored intervals.

The amounts of iron extracted with the $0.5 \mathrm{~N} \mathrm{HCl}$ and $\mathrm{Ti}^{3+}$-EDTA extractions are presented in figure 3 and listed in appendix 4 . The amount of total iron extracted by $0.5 \mathrm{~N} \mathrm{HCl}$ ranged from 1.2 to 18.8 micromoles per gram $\left(\mu\right.$ moles $\left.\mathrm{g}^{-1}\right)$. For all samples, $\mathrm{Ti}^{3+}$-EDTA released greater amounts of iron $\left(7.9\right.$ to $48 \mu$ moles $\mathrm{g}^{-1}$ ) than the $0.5 \mathrm{~N} \mathrm{HCl}$ extraction. At all sites the greatest amounts of $\mathrm{Ti}^{3+}$ EDTA-extracted iron were from samples collected above the position of the water table at the time of sample collection. The abundance of ferrous iron relative to total iron extracted with $0.5 \mathrm{~N} \mathrm{HCl}$ generally varied directly with position of the sample relative to the water table (fig. 4). Sediment samples collected above the water table, with the exception of one sample from IC 54, have $\mathrm{Fe}^{2+} / \mathrm{Fe}_{\text {total }}$ ratios $<0.25$. Below the water table there is a general increase in the ratio, with values approaching 1.0 near the bottom of the cored intervals. Results of the iron extractions on samples collected in October 2004 and April 2005 are broadly consistent with similar chemical conditions in the sediment during both sampling events.
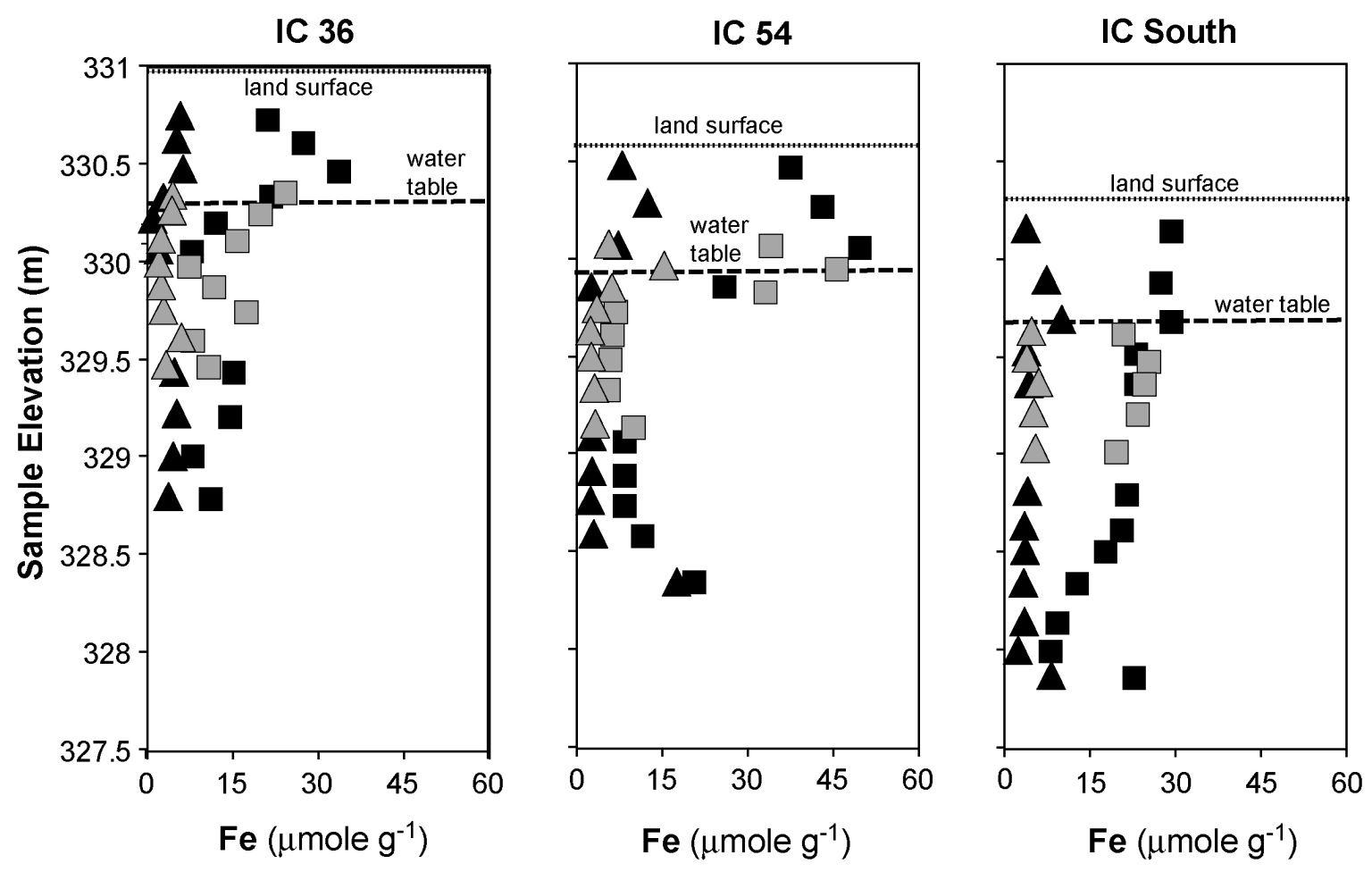

Figure 3. Depth variation in the total iron extracted using $0.5 \mathrm{~N} \mathrm{HCl}(\mathbf{\Delta})$ and $\mathrm{Ti}^{3+}-\mathrm{EDTA}(\boldsymbol{\nabla})$ on sediment samples collected at IC 36, IC 54, and IC South. Elevation of water table during the April 2005 sample collection is shown. (black, collected in October 2004; gray, collected in April 2005). 
IC 36

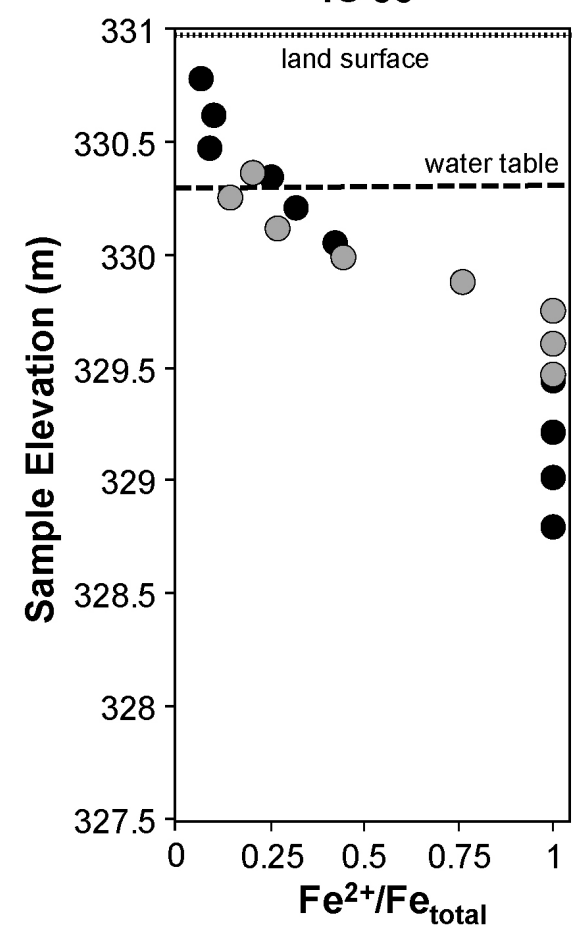

IC 54

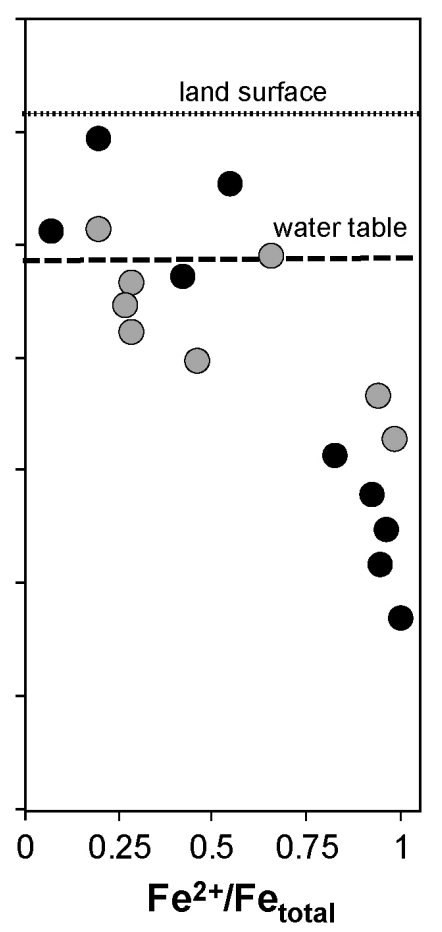

IC South

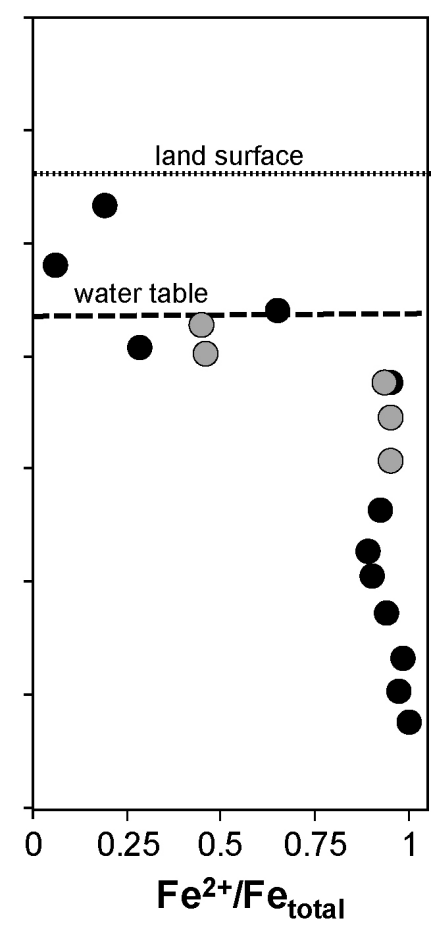

Figure 4. Depth variation in the ratio of ferrous $\left(\mathrm{Fe}^{2+}\right)$ to total iron $\left(\mathrm{Fe}_{\text {total }}\right)$ extracted with $0.5 \mathrm{~N}$ $\mathrm{HCl}$ from sediment samples collected at IC 36 , IC 54, and IC South. Elevation of water table during the April 2005 sample collection is shown as a dashed line. (black, collected in October 2004; gray, collected in April 2005).

The amount of iron extracted was also evaluated relative to the grain size of the samples. No systematic distribution of $0.5 \mathrm{~N} \mathrm{HCl}$-extractable iron with grain size distribution of the sediment was recognized. In contrast, the amount of $\mathrm{Ti}^{3+}$-EDTA-extractable iron did increase as the fraction of sediment smaller than $100 \mu \mathrm{m}$ increased (figure 5). For samples with similar contents of particles smaller than $100 \mu \mathrm{m}$, those collected above the water table generally contain markedly greater amounts of $\mathrm{Ti}^{3+}$-EDTA-extractable iron than samples from the saturated zone.

The abundances of water-soluble sulfate, acid-soluble sulfate, acid-volatile sulfide, and disulfide sulfur recovered from the sediment are listed in appendix 5 along with the $\delta^{34} S$ values of these phases. Results of the water-soluble sulfate extraction on sediment collected in October 2004 yielded only small amounts of sulfate (less than $0.5 \mu$ moles $\mathrm{g}^{-1}$ sulfate sulfur); therefore, the extraction was not applied to the April 2005 sample set. The amounts of acid-soluble sulfate recovered vary from less than 0.1 to $2.4 \mu$ moles $\mathrm{g}^{-1}$. Acid-volatile sulfide concentrations range from less than 0.1 to $3.8 \mu$ moles $\mathrm{g}^{-1}$, and disulfide sulfur varies from less than 0.1 to $15 \mu$ moles $\mathrm{g}^{-1}$. Most samples contain greater amounts of acid-volatile sulfide than disulfide sulfur.

Depth variations in the abundance of acid-volatile sulfide and disulfide sulfur are plotted on figure 6. The vertical variations in the concentrations of acid-volatile sulfide and disulfide sulfur are similar at each site, but the profiles are distinct among the IC sites. Sediment above the water table at IC 36 lacks detectable sulfide, whereas large amounts were recovered from the same depth range 
at IC 54 and minor amounts at IC South. Sediment a few tens of centimeters below the water table at all sites has lower sulfide concentrations than deeper sediment. Sulfide concentrations at IC 36 and IC 54 increase sharply in samples below the water table, while the profile for IC South portrays a more gradual increase with depth.

The range of sulfur isotope compositions of acid-soluble sulfate (4 to 20 per mil) is distinct from the values measured for acid-volatile sulfide ( -0.5 to -21.5 per mil) and disulfide sulfur ( -4 to -25.1 per mil) (fig. 7). The $\delta^{34} \mathrm{~S}$ values of acid-soluble sulfate collected at IC South are consistently smaller than those measured at IC 36 and IC 54 (fig. 7). Sulfur isotope values of acid-volatile sulfide among the three cores are generally similar, while the $\delta^{34} \mathrm{~S}$ of disulfide sulfur measured in IC 54 core is greater than at the other sites. The typically negative values for $\delta^{34} \mathrm{~S}$ of the sulfide phases relative to the values of sulfate are consistent with formation of sulfide by bacterial sulfate reduction (Breit and others, 2007).

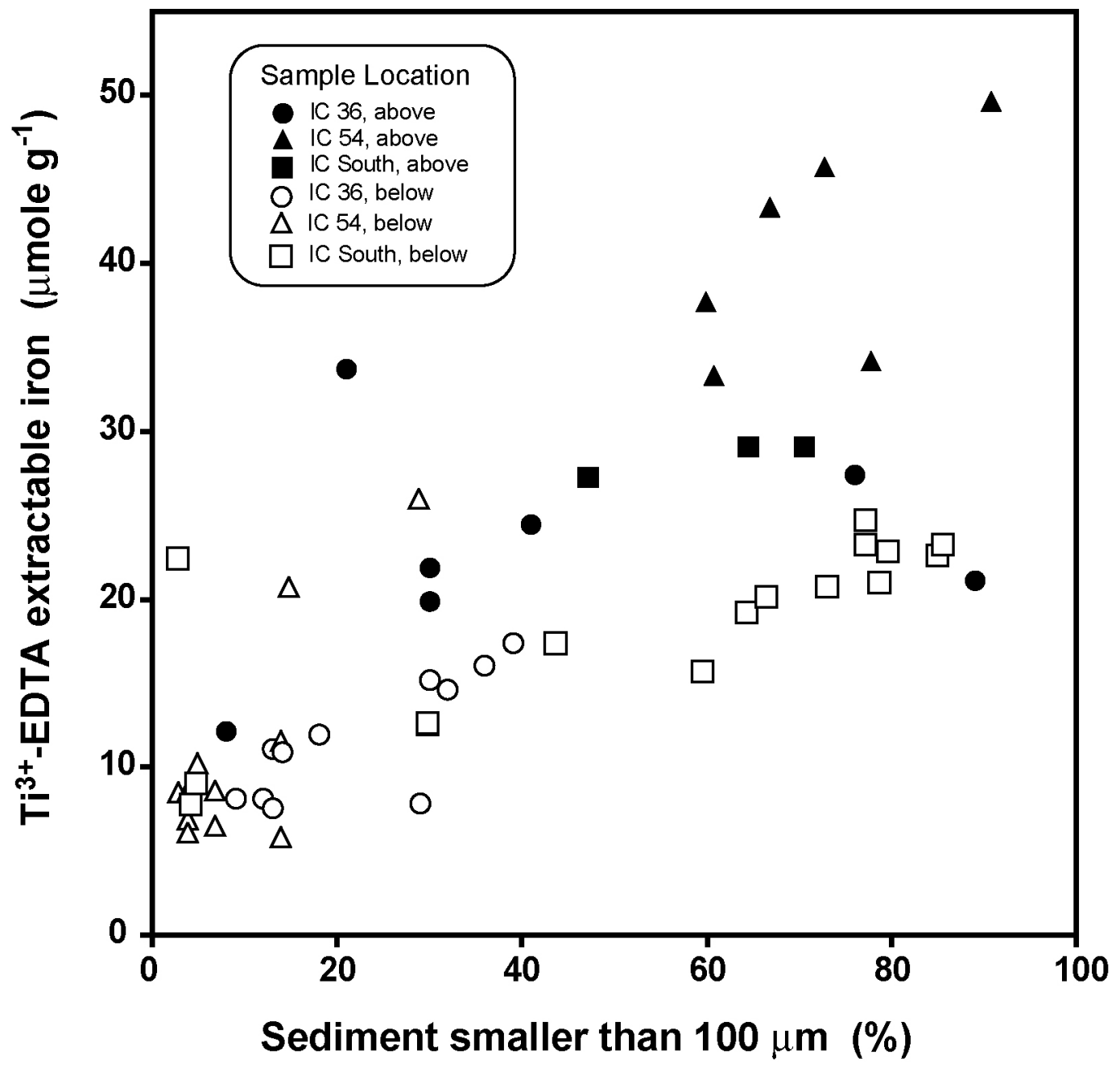

Figure 5. Abundance of iron extracted from sediment samples with $\mathrm{Ti}^{3+}$-EDTA relative to the abundance of particles smaller than $100 \mu \mathrm{m}$. ('above', samples collected above the saturated zone; 'below', samples collected within the saturated zone). 

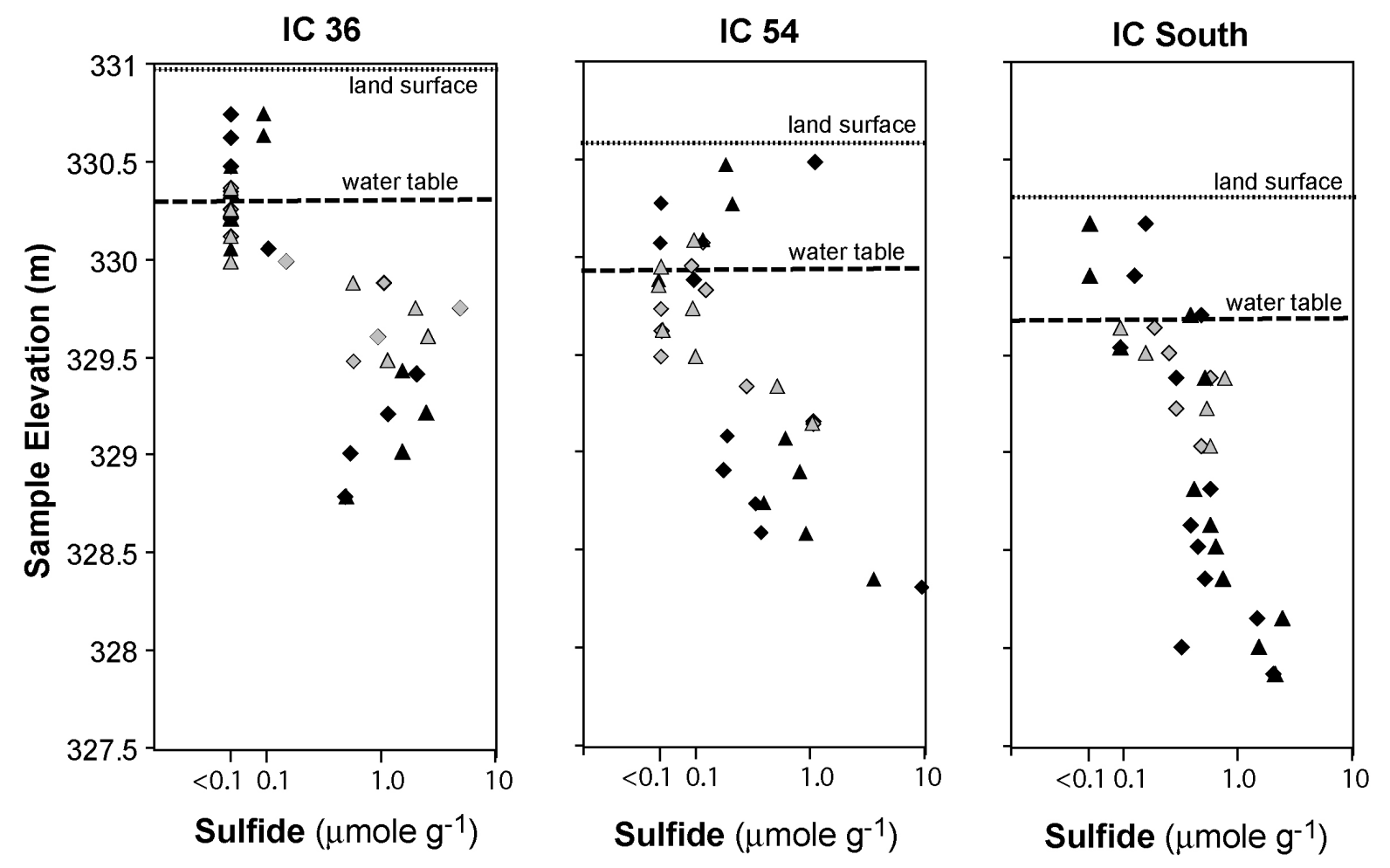

Figure 6. Depth variation in the abundance of acid-volatile sulfide $(\mathbf{\Delta})$ and disulfide $(\bullet)$ extracted from sediment collected at IC 36, IC 54, and IC South. Elevation of water table during the April 2005 sample collection is shown by the dashed line. (Black indicates samples collected in October 2004; gray indicates samples collected in April 2005). 


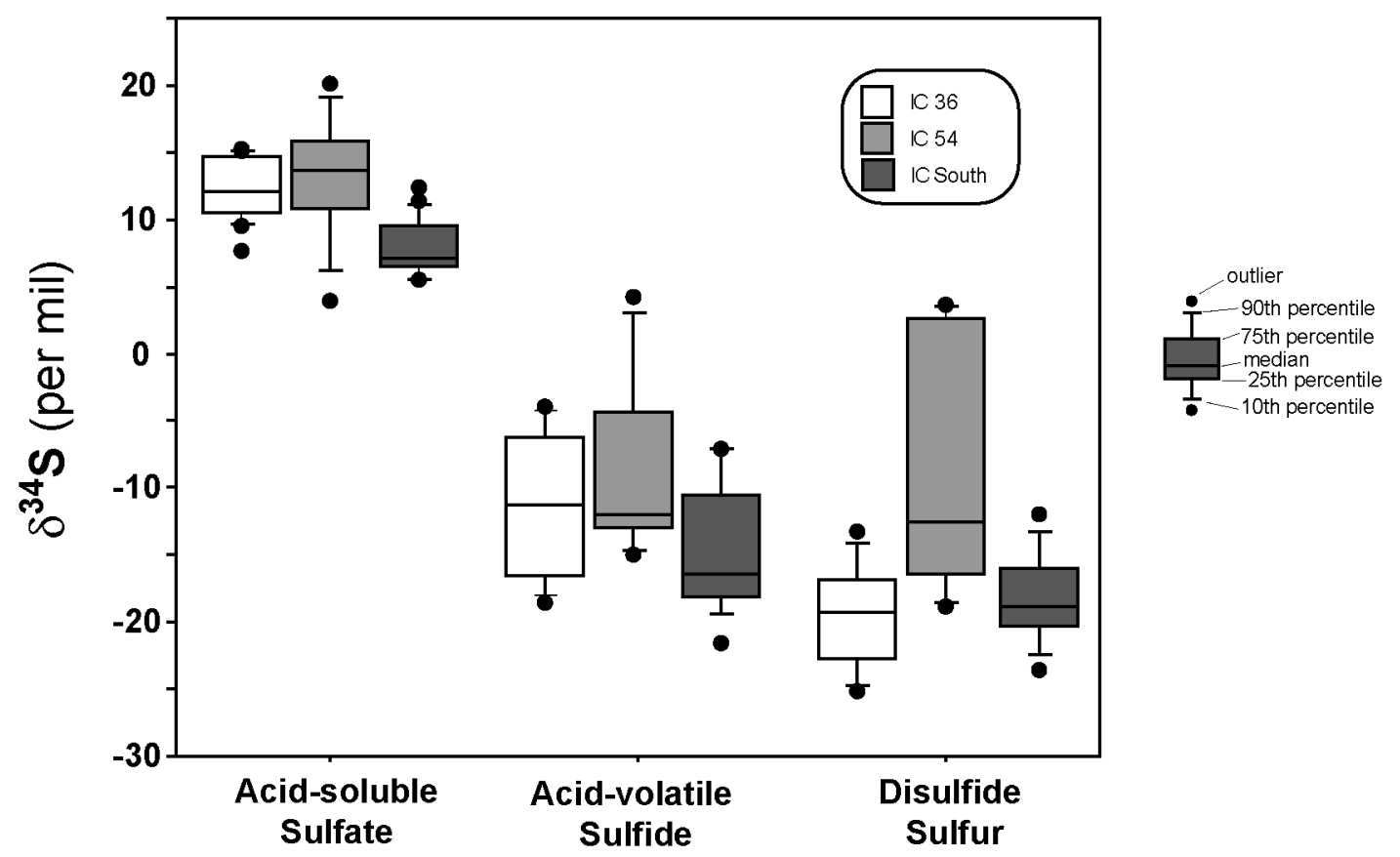

Figure 7. Box plot of the sulfur isotope composition of sulfur species extracted from the sediment samples collected at IC 36, IC 54 and IC South.

\section{Water Composition}

The composition of water samples is presented in appendix 6 and summarized in table 2 . In general, the concentration of dissolved constituents at the IC site follows the vertical trends described by Scholl and others $(2005,2006)$. Low concentrations of most measured constituents were detected at shallow depths at all three sites. This tendency is indicated in the profiles of chloride concentration at IC 36 and IC South (fig. 8).

Dissolved iron concentrations generally increase with depth, but the trends vary at each IC site (fig. 9). Sample preservation problems limited the iron analyses of water samples from IC 36 that were collected in October, but the April samples suggest two maxima in iron content.

Samples from IC 54 have low dissolved iron contents without a clear maximum for samples gathered in October, whereas the April samples define a maximum $1.0 \mathrm{~m}$ below the ground surface and an increase in iron concentration in the two deepest wells. The profile for IC South is similar for both the October and April sampling, with maxima at approximately $1.5 \mathrm{~m}$ depth.

The concentration of dissolved sulfate increases with depth to a maximum value and then declines to concentrations near the limit of detection at all sites (fig. 10). The depth of the maxima is similar in both the October and April sampling, although the concentrations that define the maxima are greater in October. 
Table 2. Statistical summary of parameters measured on ground water samples collected from IC wells in October 2004 and April 2005.

[Sp. Cond. - specific conductance; $\mu \mathrm{S} / \mathrm{cm}$, microSiemens per centimeter; DOC, dissolved organic carbon; mg/L, milligrams per liter ].

\begin{tabular}{|c|c|c|c|c|}
\hline & & IC 36 & IC 54 & IC South \\
\hline \multicolumn{5}{|c|}{ H } \\
\hline & Median & 7.07 & 7.24 & 7.10 \\
\hline & Minimum & 6.78 & 6.75 & 6.07 \\
\hline & Maximum & 7.49 & 7.70 & 7.80 \\
\hline
\end{tabular}

\begin{tabular}{|rccc|} 
Sp. Cond. $(\boldsymbol{\mu S} / \mathbf{c m})$ \\
Median & 3600 & 1400 & 920 \\
Minimum & 600 & 1100 & 620 \\
Maximum & 4800 & 2400 & 1500 \\
\hline
\end{tabular}

\begin{tabular}{|rccc|} 
Calcium (mg/L) & & & \\
\hline Median & 99 & 96 & 160 \\
Minimum & 67 & 50 & 100 \\
Maximum & 240 & 170 & 200 \\
\hline
\end{tabular}

\begin{tabular}{|rccc|} 
Magnesium (mg/L) & & & \\
\hline Median & 55 & 35 & 19 \\
Minimum & 7.5 & 22 & 8.0 \\
Maximum & 95 & 59 & 45 \\
\hline
\end{tabular}

\begin{tabular}{|rccc|} 
Potassium (mg/L) & & & \\
\hline Median & 150 & 6.4 & 4.2 \\
Minimum & 0.6 & 4.5 & 1.3 \\
Maximum & 230 & 9.1 & 5.2 \\
\hline Sodium (mg/L) & & & \\
\hline Median & 350 & 190 & 14 \\
Minimum & 0.6 & 77 & 5.4 \\
Maximum & 530 & 310 & 110 \\
\hline
\end{tabular}

\begin{tabular}{|c|c|c|c|}
\hline & IC 36 & IC 54 & IC South \\
\hline \multicolumn{4}{|l|}{ Iron (mg/L) } \\
\hline Median & 7.8 & 1.9 & 3.6 \\
\hline Minimum & 0.1 & 0.3 & 0.02 \\
\hline Maximum & 14 & 7.8 & 8.6 \\
\hline \multicolumn{4}{|l|}{ Ammonium (mg/L) } \\
\hline Median & 65 & 2.8 & 1.0 \\
\hline Minimum & $<0.7$ & $<0.7$ & $<0.7$ \\
\hline Maximum & 430 & 8.6 & 4.1 \\
\hline \multicolumn{4}{|l|}{$\mathrm{DOC}$ (mg/L) } \\
\hline Median & 57 & 20 & 5.8 \\
\hline Minimum & 6.0 & 2.1 & 1.1 \\
\hline Maximum & 92 & 32 & 11 \\
\hline \multicolumn{4}{|l|}{ Bicarbonate (mg/L) } \\
\hline Median & 1850 & 864 & 578 \\
\hline Minimum & 337 & 765 & 278 \\
\hline Maximum & 2330 & 1150 & 830 \\
\hline \multicolumn{4}{|l|}{ Chloride (mg/L) } \\
\hline Median & 255 & 81 & 7.2 \\
\hline Minimum & 8.9 & 41 & 0.3 \\
\hline Maximum & 396 & 256 & 134 \\
\hline \multicolumn{4}{|l|}{ Sulfate (mg/L) } \\
\hline Median & 18 & 21 & 27 \\
\hline Minimum & 0.2 & 0.2 & 4.7 \\
\hline Maximum & 78 & 120 & 130 \\
\hline
\end{tabular}


The major ion characteristics of water samples are depicted on a Piper plot (fig. 11) in which the bicarbonate concentration is multiplied by 0.1 to enhance contrast in anion composition among the water samples. Water samples from IC 36 and IC 54 tend to have consistently greater proportions of chloride than most samples from IC South. Similarly, IC 36 and IC 54 have a greater relative content of sodium than ground water sampled from IC South.

IC 36

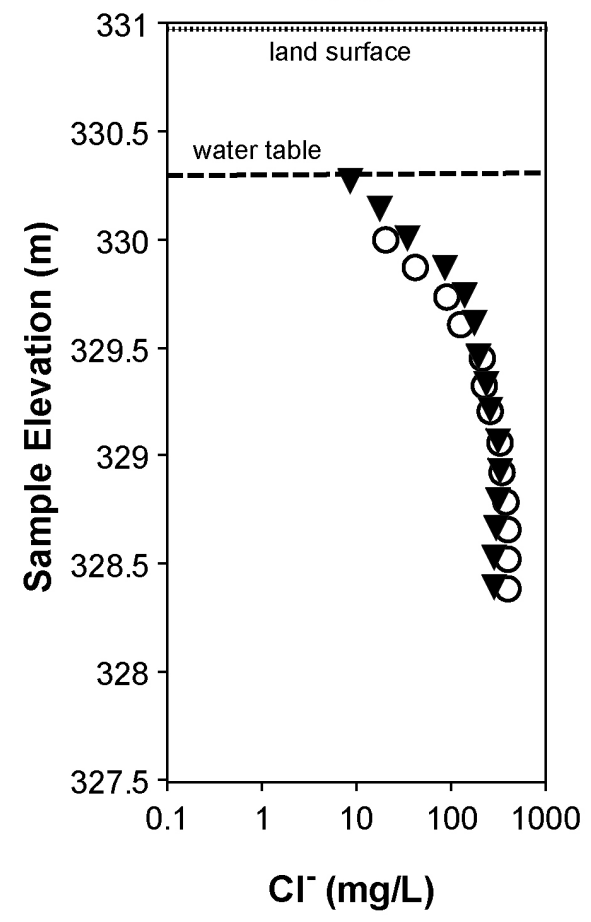

IC 54

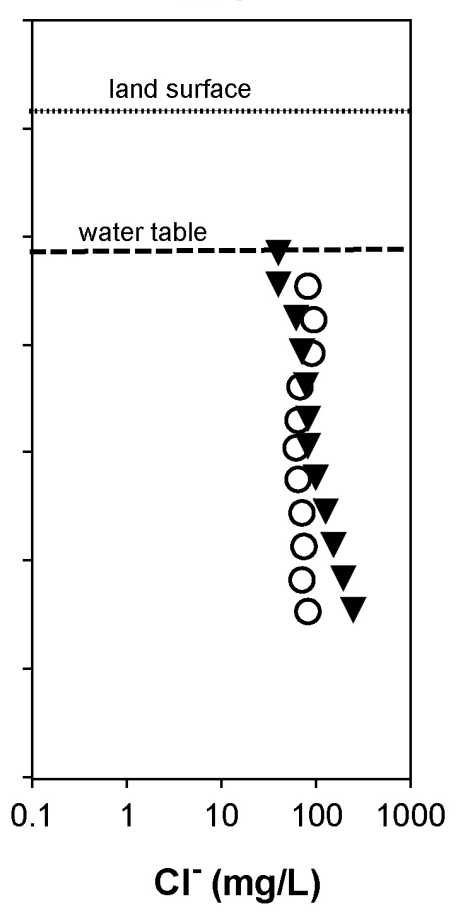

IC South

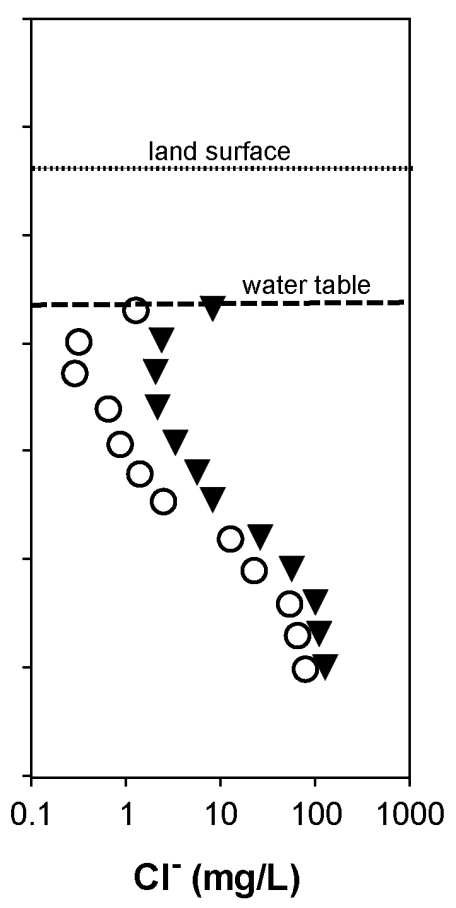

Figure 8. Depth variation of chloride concentration of ground water sampled from the wells at IC 36, IC 54, and IC South in October 2004 (O) and April 2005 ( $\nabla$ ). 
IC 36

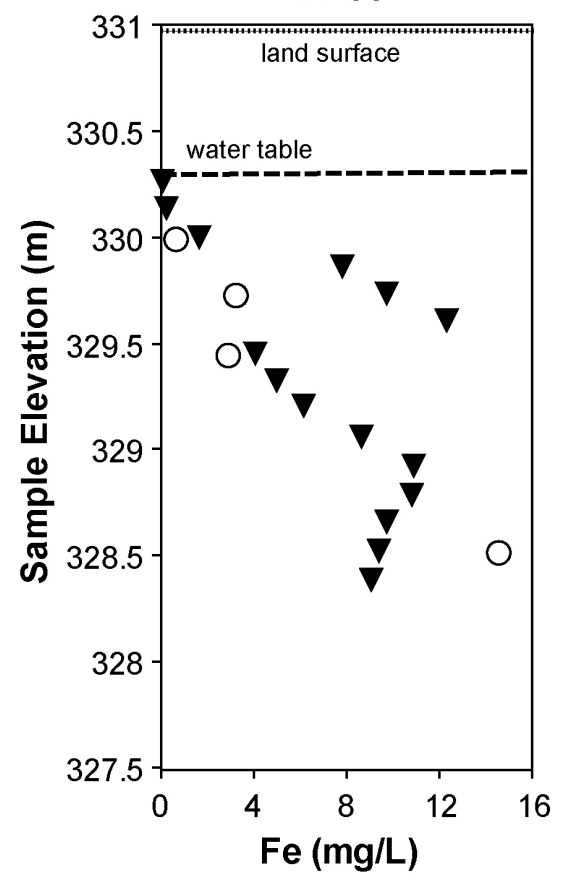

IC 54

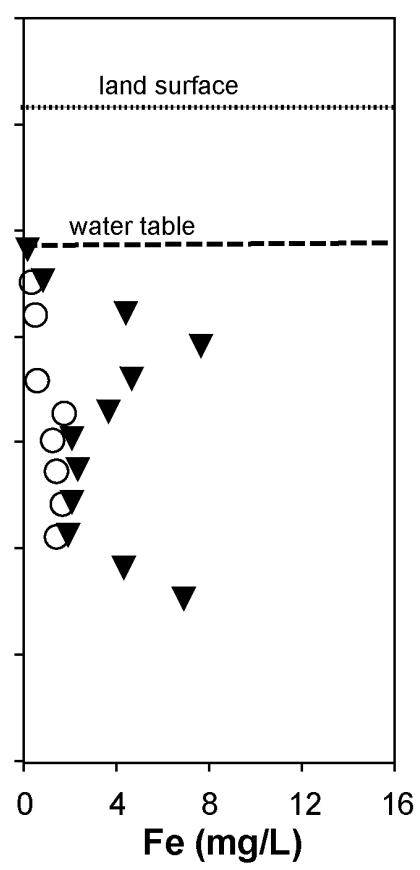

IC South

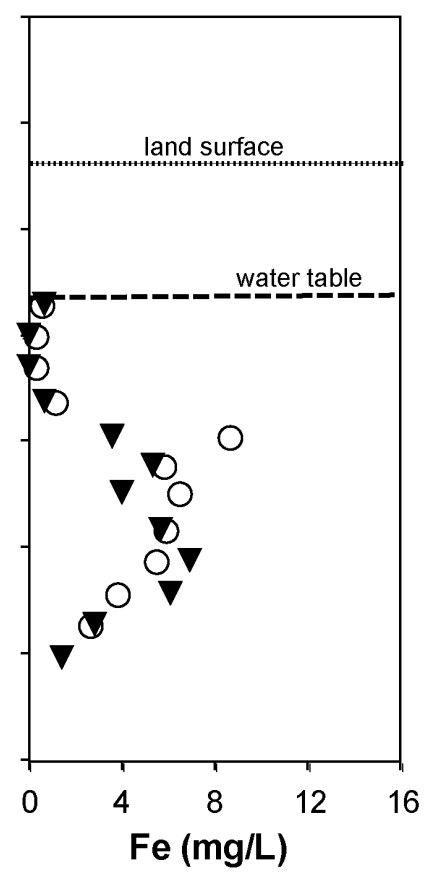

Figure 9. Depth variation in iron concentration of ground water from the wells at IC 36, IC 54, and IC South in October 2004 (O) and April 2005 ( $\nabla)$.

IC 36

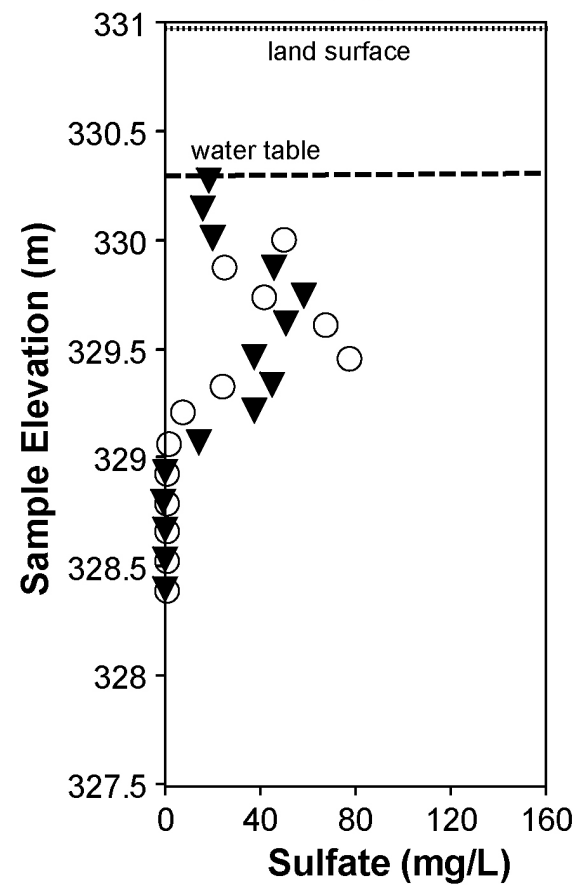

IC 54

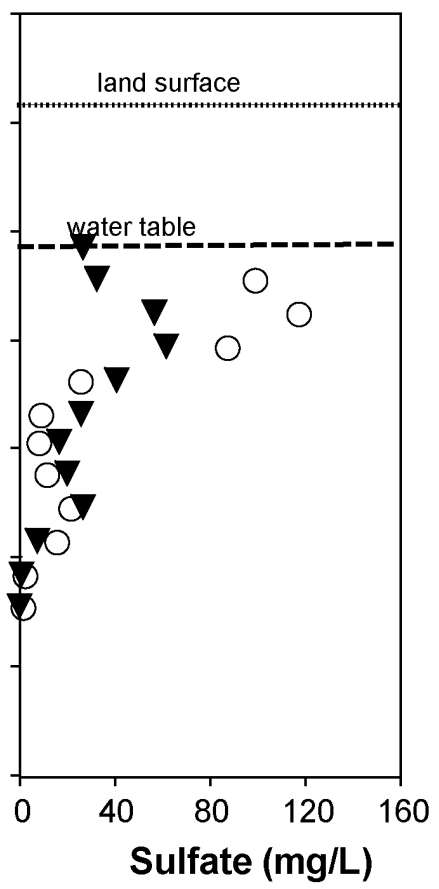

IC South

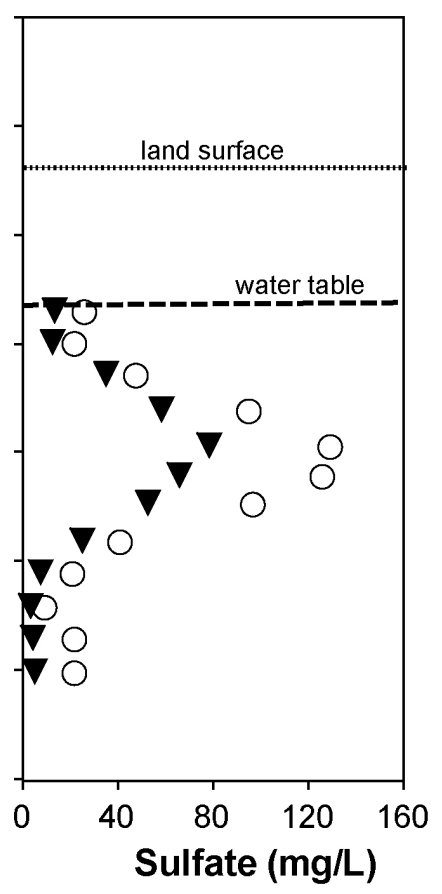

Figure 10. Depth variation of sulfate concentration of ground water sampled from the wells at IC 36, IC 54, and IC South in October 2004 (O) and April 2005 ( $\nabla)$. Elevation of water table during the April 2005 sample collection is shown by the dashed line. 


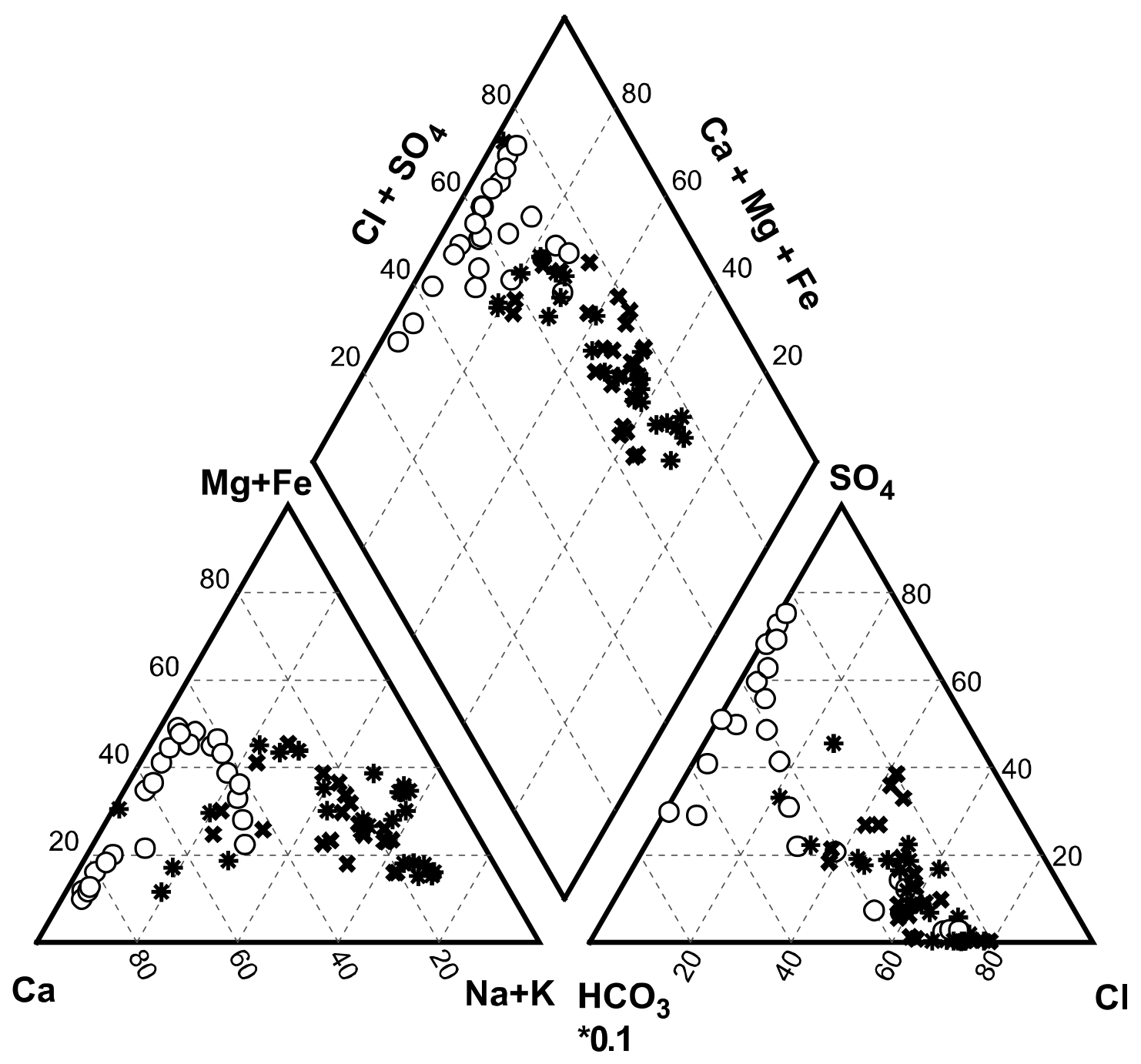

Figure 11. Piper diagram of major ion composition water samples collected from the wells at IC $36(*)$, IC $54(\mathbf{x})$, and IC South (O). Note that the bicarbonate concentration is multiplied by 0.1 . 


\section{References Cited}

Baedecker, M.J., and Cozzarelli, I.M., 1992, The determination and fate of unstable constituents of contaminated groundwater, in Lesage, Suzanne and Jackson, R.E., Groundwater contamination and analysis at hazardous waste sites: Environmental Science and Pollution Control Series, 4, New York, Marcel Dekker, p. 425-461.

Becker, C.J., 2002, Hydrology and leachate plume delineation at a closed municpal landfill, Norman, Oklahoma: U.S. Geological Survey, Water-Resources Investigations Report 01-4168, 36 p.

Breit, G.N., Tuttle, M.L.W., and Cozzarelli, I.M., 2007. Using $\delta^{34} S$ and $\delta^{18} \mathrm{O}$ of sulfate to resolve processes affecting sulfur in alluvium beneath a riparian area, Oklahoma: Geological Society of America Abstracts with Program, v. 39, no. 6, p. 481.

Breit, G.N., Tuttle, M.L.W., Cozzarelli, I.M., Christenson, S.C., Jaeschke, J.B., Fey, D.L., and Berry, C.J., 2005, Results of the chemical and isotopic analyses of sediment and water from alluvium of the Canadian River near a closed municipal landfill, Norman, Oklahoma: U.S. Geological Survey Open-File Report 2005-1091, 37 p.

Clesceri, L.S., Freenber, A.E., and Eaton, A.D., eds., 1998, 3500-Iron B. Phenanthroline method in Standard Methods for the Examination of Water and Wastewater 20th ed.: Washington, D.C., American Public Health Association, p. 3-76 to 3-78.

Cozzarelli, I.M., Suflita, J.M., Ulrich, G.A., Harris, S.H., Scholl, M.A., Schlottmann, J.L., and Christenson, Scott, 2000, Geochemical and microbiological methods for evaluating anaerobic processes in an aquifer contaminated by landfill leachate: Environmental Science and Technology, v. 34, p. 4025-4033.

Heron, Gorm, Crouzet, Catherine, Bourg, A.C.M., and Christensen, T.H., 1994, Speciation of $\mathrm{Fe}(\mathrm{II})$ and $\mathrm{Fe}$ (III) in contaminated aquifer sediments using chemical extraction techniques: Environmental Science and Technology, v. 28, p. 1698-1705.

Kester, C.L., Rye, R.O., Johnson, C.A., Schwartz, Ch., and Homes, Ch., 2001, On-line sulfur isotope analysis of organic material by direct combustion: preliminary results and potential applications: Isotopes in Environmental Health Studies, v. 37, p. 53-65.

Qian, Jianguo, and Mopper, Kenneth, 1996, Automated high performance, high temperature combustion total organic carbon analyzer: Analytical Chemistry, v. 68, p. 3090-3097.

Rice, C.A., Tuttle, M.L., and Reynolds, R.L., 1993, The analysis of forms of sulfur in ancient sediments and sedimentary rocks: comments and cautions: Chemical Geology, v. 107, p. 83-95. 
Schlottmann, J.L, 2001, Water chemistry near the closed Norman Landfill, Cleveland County, Oklahoma: U.S. Geological Survey Water-Resources Investigations Report 004238, $44 \mathrm{p}$.

Scholl, M.A., and Christenson, S.C., 1998, Spatial variation in hydraulic conductivity determined by slug tests in the Canadian River alluvium near the Norman Landfill, Norman, Oklahoma: U.S. Geological Survey Water-Resources Investigations Report 97-4292, $28 \mathrm{p}$

Scholl, M.A., Christenson, S.C., Cozzarelli, I.M., Ferree, D.M., and Jaeschke, J., 2005, Recharge processes in an alluvial aquifer riparian zone, Norman Landfill, Norman, Oklahoma, 1998-2000: U.S. Geological Survey Scientific Investigations Report 20045238, 27 p.

Scholl, M.A., Cozzarelli, I.M., and Christenson, S.C., 2006, Recharge processes drive sulfate reduction in an alluvial aquifer contaminated with landfill leachate: Journal of Contaminant Hydrology, v. 86, p. 239-261.

Steiner, Frederick, Pieart, Scott, Cook, Edward, Rich, Jacqueline, and Coltman, Virginia, 1994, State wetlands and riparian area protection programs: Environmental Management, v. 18, p. 183-201.

Tuttle, M.L., Goldhaber, M.B., and Williamson, D.L., 1986, An analytical scheme for determining forms of sulfur in oil shales and associated rocks: Talanta, v. 33, p. 953961. 
Appendix 1. Depth intervals of the wells sampled at IC 36, IC 54 and IC South. Elevations are in meters and are relative to the North American Vertical Datum of 1988.

\begin{tabular}{cccc}
\hline Well Site & $\begin{array}{c}\text { Well } \\
\text { Number }\end{array}$ & $\begin{array}{c}\text { Top } \\
\text { Elevation }\end{array}$ & Bottom Elevation \\
\hline IC 36 & 3 & 330.33 & 330.19 \\
IC 36 & 4 & 330.20 & 330.06 \\
IC 36 & 5 & 330.06 & 329.93 \\
IC 36 & 6 & 330.94 & 329.80 \\
IC 36 & 7 & 329.80 & 329.66 \\
IC 36 & 8 & 329.67 & 329.54 \\
IC 36 & 9 & 329.52 & 329.38 \\
IC 36 & 10 & 329.39 & 329.25 \\
IC 36 & 11 & 329.27 & 329.13 \\
IC 36 & 12 & 329.13 & 328.99 \\
IC 36 & 13 & 328.99 & 328.85 \\
IC 36 & 14 & 328.85 & 328.72 \\
IC 36 & 15 & 328.72 & 328.59 \\
IC 36 & 16 & 328.59 & 328.45 \\
IC 36 & 17 & 328.45 & 328.32 \\
IC 54 & 3 & 329.99 & 329.84 \\
IC 54 & 4 & 329.84 & 329.69 \\
IC 54 & 5 & 329.69 & 329.54 \\
IC 54 & 6 & 329.54 & 329.38 \\
IC 54 & 7 & 329.38 & 329.23 \\
IC 54 & 8 & 329.23 & 329.07 \\
IC 54 & 9 & 329.10 & 328.95 \\
IC 54 & 10 & 328.95 & 328.80 \\
IC 54 & 11 & 328.80 & 328.64 \\
IC 54 & 12 & 328.64 & 328.49 \\
IC 54 & 13 & 328.49 & 328.34 \\
IC 54 & 14 & 328.34 & 328.19 \\
IC South & 3 & 329.73 & 329.58 \\
IC South & 4 & 329.58 & 329.43 \\
IC South & 5 & 329.43 & 329.28 \\
IC South & 6 & 329.27 & 329.12 \\
IC South & 7 & 329.11 & 328.96 \\
IC South & 8 & 328.97 & 328.82 \\
IC South & 9 & 328.84 & 328.69 \\
IC South & 10 & 328.67 & 328.52 \\
IC South & 11 & 328.52 & 328.37 \\
IC South & 12 & 328.37 & 328.07 \\
IC South & 13 & 328.07 & \\
IC South & 14 & & \\
\hline
\end{tabular}


Appendix 2. Elevation and description of cored sediment samples. Elevations are reported relative to North American Vertical Datum of 1988.

\begin{tabular}{|c|c|c|c|}
\hline Sample Number & $\begin{array}{l}\text { Sample } \\
\text { Upper Elevation (m) }\end{array}$ & $\begin{array}{l}\text { Interval } \\
\quad \text { Lower Elevation (m) }\end{array}$ & Sediment Description \\
\hline IC 36-04-A & 330.80 & 330.69 & $\begin{array}{l}\text { red-brown, laminated, clayey, fine sand; overlying sand is mixed } \\
\text { with landfill trash fragments }\end{array}$ \\
\hline IC 36-04-B & 330.69 & 330.55 & red, laminated, fine sand \\
\hline IC 36-04-C & 330.55 & 330.41 & red-brown, laminated, clayey, fine-medium sand \\
\hline IC 36-04-D & 330.41 & 330.28 & red-brown, laminated, medium sand \\
\hline IC 36-04-E & 330.28 & 330.14 & brown, laminated, clayey, medium sand \\
\hline IC 36-04-F & 330.14 & 329.97 & gray-brown, massive, medium sand \\
\hline IC 36-04-G & 329.56 & 329.33 & gray-brown, massive, medium sand \\
\hline IC 36-04-H & 329.33 & 329.11 & gray-brown, massive, medium sand \\
\hline IC 36-04-I & 329.11 & 328.93 & gray-brown, massive, medium sand \\
\hline IC 36-04-J & 328.93 & 328.66 & red-gray-brown, massive, medium sand \\
\hline IC 36-05-A & 330.4 & 330.32 & red-brown, fine sand \\
\hline IC 36-05-B & 330.32 & 330.19 & red brown, bedded, medium sand \\
\hline IC 36-05-C & 330.19 & 330.04 & red-brown, bedded, fine-medium sand \\
\hline IC 36-05-D & 330.04 & 329.94 & red-brown, massive, medium to coarse sand \\
\hline IC 36-05-E & 329.94 & 329.82 & gray-brown, medium sand with sparse clay partings \\
\hline IC 36-05-F & 329.82 & 329.68 & $\begin{array}{l}\text { gray-brown, medium sand with laminae of dark-brown clay and } \\
\text { fragments of carbonized plant fragments }\end{array}$ \\
\hline IC 36-05-G & 329.68 & 329.53 & gray-brown, massive, medium sand \\
\hline IC 36-05-H & 329.53 & 329.41 & gray-brown, massive, medium sand \\
\hline IC 54-04-A & 330.56 & 330.38 & Brown, fine sand overlying brown silt \\
\hline IC 54-04-B & 330.38 & 330.16 & red-brown, fine sand with interbedded brown clayey silt \\
\hline IC 54-04-C & 330.16 & 329.96 & red-brown, laminated, silt and fine sand \\
\hline IC 54-04-D & 329.96 & 329.75 & red, laminated, medium sand \\
\hline IC 54-04-E & 329.16 & 328.97 & gray-brown, massive, medium sand \\
\hline IC 54-04-F & 328.97 & 328.82 & gray-brown, medium sand \\
\hline IC 54-04-G & 328.82 & 328.66 & brown, massive, medium sand \\
\hline IC 54-04-H & 328.66 & 328.51 & gray-brown, medium sand \\
\hline IC 54-04-I & 328.40 & 328.30 & $\begin{array}{l}\text { intraclast conglomerate of red-brown, clayey, silt clasts, and pale } \\
\text { red-brown coarse-medium sand with carbonized wood fragments }\end{array}$ \\
\hline IC 54-05-A & 330.12 & 330.01 & red-brown, fine sand \\
\hline IC 54-05-B & 330.01 & 329.89 & red-brown, silt \\
\hline
\end{tabular}


Appendix 2. Elevation and description of cored sediment samples - Continued.

\begin{tabular}{|c|c|c|c|}
\hline Sample Number & $\begin{array}{r}\text { Samp } \\
\text { Upper Elevation (m) }\end{array}$ & $\begin{array}{l}\text { Interval } \\
\text { Lower Elevation (m) }\end{array}$ & Sediment Description \\
\hline IC 54-05-C & 329.89 & 329.77 & red-brown, laminated, fine sand \\
\hline IC 54-05-D & 329.77 & 329.69 & red, medium sand \\
\hline IC 54-05-E & 329.69 & 329.54 & red, faintly bedded, medium sand \\
\hline IC 54-05-F & 329.54 & 329.40 & light red-brown, medium sand \\
\hline IC 54-05-G & 329.40 & 329.23 & gray-brown, medium-fine sand with distorted bedding \\
\hline IC 54-05-H & 329.23 & 329.05 & gray-brown, massive, medium sand with a few granules \\
\hline IC South-04-A & 330.01 & 329.71 & red, laminated, fine sand \\
\hline IC South-04-B & 329.71 & 329.47 & red, laminated, fine-medium sand intebedded with red, silty-sand \\
\hline IC South-04-C & 329.47 & 329.31 & $\begin{array}{l}\text { red-brown, laminated, clayey, fine sand with dark red-brown clay } \\
\text { granules and small carbonized wood fragments }\end{array}$ \\
\hline IC South-04-D & 329.31 & 329.15 & red-brown, clayey, fine sand \\
\hline IC South-04-E & 329.15 & 329.00 & red-brown, fine sand with silty laminae \\
\hline IC South-04-F & 328.61 & 328.40 & red, massive, fine sand \\
\hline IC South-04-G & 328.40 & 328.26 & red, massive, fine sand \\
\hline IC South-04-H & 328.26 & 328.18 & red-brown, fine-medium sand \\
\hline IC South-04-I & 328.18 & 327.92 & $\begin{array}{l}\text { upper } 8 \mathrm{~cm} \text { is red-brown, medium sand; lower } 9 \mathrm{~cm} \text { is gray-brown, } \\
\text { upper medium sand with minor mud-clast fragments }\end{array}$ \\
\hline IC South-04-J & 327.92 & 327.78 & red-brown, upper medium sand, with deformed clayey silt laminae \\
\hline IC South-04-K & 327.78 & 327.63 & red-brown, upper medium sand with mud clasts and snail shells \\
\hline IC South-04-L & 327.63 & 327.51 & red-brown, upper medium sand with mud clast \\
\hline IC South-05-A & 329.69 & 329.58 & red-brown, laminated, fine sand with carbonized wood fragments \\
\hline IC South-05-B & 329.58 & 329.43 & red, faintly laminated, fine sand \\
\hline IC South-05-C & 329.43 & 329.33 & red-brown, laminated, fine sand \\
\hline IC South-05-D & 329.33 & 329.12 & red, with faintly visible distorted bedding, fine sand \\
\hline IC South-05-E & 329.12 & 328.93 & brown, medium-fine sand \\
\hline
\end{tabular}


Appendix 3. Results of the grain-size analysis of sediment samples.

\begin{tabular}{|c|c|c|c|c|c|}
\hline Sample Number & $\begin{array}{c}>500 \mu \mathrm{m} \\
\text { (wt. } \%)\end{array}$ & $\begin{array}{l}500 \text { to } 250 \mu \mathrm{m} \\
\text { (wt. } \% \text { ) }\end{array}$ & $\begin{array}{l}250 \text { to100 } \mu \mathrm{m} \\
(w \mathrm{wt} \%)\end{array}$ & $\begin{array}{c}100 \text { to } 62 \mu \mathrm{m} \\
\text { (wt.\%) }\end{array}$ & $\begin{array}{l}<62 \mu \mathrm{m} \\
\text { (wt. \%) }\end{array}$ \\
\hline IC 36-04-A & $<1$ & 1 & 10 & 79 & 10 \\
\hline IC 36-04-B & $<1$ & 6 & 18 & 64 & 12 \\
\hline IC 36-04-C & $<1$ & 13 & 65 & 19 & 2 \\
\hline IC 36-04-D & 1 & 19 & 50 & 26 & 4 \\
\hline IC 36-04-E & 1 & 33 & 57 & 8 & $<1$ \\
\hline IC 36-04-F & $<1$ & 20 & 50 & 27 & 2 \\
\hline IC $36-04-\mathrm{G}$ & 1 & 15 & 54 & 28 & 2 \\
\hline IC $36-04-\mathrm{H}$ & 4 & 19 & 45 & 29 & 3 \\
\hline IC 36-04-I & $<1$ & 32 & 55 & 11 & 1 \\
\hline IC 36-04-J & $<1$ & 44 & 43 & 11 & 2 \\
\hline IC 36-05-A & $<1$ & 13 & 46 & 34 & 7 \\
\hline IC 36-05-B & $<1$ & 14 & 56 & 27 & 3 \\
\hline IC 36-05-C & $<1$ & 11 & 54 & 33 & 3 \\
\hline IC 36-05-D & 1 & 41 & 44 & 12 & 1 \\
\hline IC 36-05-E & 1 & 23 & 58 & 17 & 1 \\
\hline IC $36-05-F$ & $<1$ & 7 & 54 & 36 & 3 \\
\hline IC $36-05-\mathrm{G}$ & 2 & 34 & 55 & 7 & 2 \\
\hline IC $36-05-\mathrm{H}$ & 1 & 38 & 48 & 12 & 2 \\
\hline IC 54-04-A & 12 & 4 & 24 & 29 & 31 \\
\hline IC 54-04-B & $<1$ & $<1$ & 33 & 27 & 40 \\
\hline IC 54-04-C & $<1$ & $<1$ & 9 & 42 & 49 \\
\hline IC 54-04-D & $<1$ & 20 & 50 & 27 & 2 \\
\hline IC 54-04-E & 1 & 23 & 73 & 2 & 1 \\
\hline IC 54-04-F & $<1$ & 26 & 71 & 3 & 1 \\
\hline IC 54-04-G & $<1$ & 19 & 74 & 6 & 1 \\
\hline IC 54-04-H & $<1$ & 21 & 66 & 13 & 1 \\
\hline IC 54-04-I & 4 & 35 & 47 & 7 & 8 \\
\hline
\end{tabular}


Appendix 3. Results of the grain-size analysis of sediment samples - Continued.

\begin{tabular}{|c|c|c|c|c|c|}
\hline Sample Number & $\begin{array}{c}>500 \mu \mathrm{m} \\
(w \mathrm{t} . \%)\end{array}$ & $\begin{array}{c}500 \text { to } 250 \mu \mathrm{m} \\
\text { (wt.\%) }\end{array}$ & $\begin{array}{l}250 \text { to100 } \mu \mathrm{m} \\
(w \mathrm{~m} . \%)\end{array}$ & $\begin{array}{c}100 \text { to } 62 \mu \mathrm{m} \\
\text { (wt.\%) }\end{array}$ & $\begin{array}{l}<62 \mu \mathrm{m} \\
\text { (wt.\%) }\end{array}$ \\
\hline IC 54-05-A & $<1$ & 1 & 21 & 27 & 51 \\
\hline IC 54-05-B & $<1$ & $<1$ & 26 & 29 & 44 \\
\hline IC 54-05-C & $<1$ & 2 & 37 & 55 & 6 \\
\hline IC 54-05-D & $<1$ & 32 & 65 & 3 & 1 \\
\hline IC 54-05-E & $<1$ & 46 & 46 & 7 & $<1$ \\
\hline IC 54-05-F & 5 & 60 & 32 & 4 & $<1$ \\
\hline IC 54-05-G & $<1$ & 24 & 61 & 13 & 1 \\
\hline IC $54-05-\mathrm{H}$ & 1 & 37 & 57 & 4 & 1 \\
\hline IC South-04-A & $<1$ & 4 & 26 & 64 & 6 \\
\hline IC South-04-B & 1 & 7 & 45 & 39 & 8 \\
\hline IC South-04-C & $<1$ & 1 & 34 & 60 & 4 \\
\hline IC South-04-D & $<1$ & $<1$ & 21 & 79 & 1 \\
\hline IC South-04-E & $<1$ & $<1$ & 15 & 79 & 6 \\
\hline IC South-04-F & $<1$ & $<1$ & 21 & 71 & 8 \\
\hline IC South-04-G & $<1$ & $<1$ & 34 & 62 & 4 \\
\hline IC South-04-H & $<1$ & 2 & 55 & 41 & 2 \\
\hline IC South-04-I & 3 & 21 & 46 & 28 & 2 \\
\hline IC South-04-J & 10 & 59 & 26 & 4 & 1 \\
\hline IC South-04-K & 7 & 60 & 28 & 3 & 1 \\
\hline IC South-04-L & 10 & 66 & 21 & 2 & 1 \\
\hline IC South-05-A & $<1$ & $<1$ & 27 & 69 & 4 \\
\hline IC South-05-B & $<1$ & $<1$ & 23 & 72 & 4 \\
\hline IC South-05-C & $<1$ & $<1$ & 14 & 80 & 5 \\
\hline IC South-05-D & $<1$ & $<1$ & 23 & 70 & 7 \\
\hline IC South-05-E & $<1$ & 1 & 35 & 59 & 5 \\
\hline
\end{tabular}


Appendix 4. Concentration of iron sequentially extracted from the sediment samples using $0.5 \mathrm{~N}$ $\mathrm{HCl}$ and $\mathrm{Ti}^{3+}$-EDTA. Concentrations were calculated on an air-dried sediment basis.

[ppm, parts per million; $\mathrm{Fe}^{2+}$, ferrous iron; $\mathrm{Fe}_{\text {total }}$, sum of ferrous and ferric iron]

\begin{tabular}{|c|c|c|c|c|}
\hline Sample Number & $\begin{array}{c}\mathrm{Fe}^{2+} \\
0.5 \mathrm{~N} \mathrm{HCl}^{-1} \\
\left(\mu \mathrm{mole} \mathrm{g}^{-1}\right) \\
\end{array}$ & $\begin{array}{c}F_{\text {total }} \\
0.5 \mathrm{~N} \mathrm{HCl}^{-1} \\
\left(\mu \mathrm{mole} \mathrm{g}^{-1}\right)\end{array}$ & $\begin{array}{l}\mathrm{Fe}^{2+} / \mathrm{Fe}_{\text {total }} \\
0.5 \mathrm{NCl}\end{array}$ & $\begin{array}{c}\mathrm{Fe} \\
\mathrm{Ti}^{3+} \text {-EDTA } \\
\left(\mu \mathrm{mole} \mathrm{g}^{-1}\right)\end{array}$ \\
\hline IC 36-04-A & 0.3 & 6.3 & 0.05 & 21.1 \\
\hline IC 36-04-B & 0.5 & 5.4 & 0.10 & 27.4 \\
\hline IC 36-04-C & 0.5 & 6.1 & 0.09 & 33.7 \\
\hline IC 36-04-D & 0.6 & 2.3 & 0.26 & 21.8 \\
\hline IC 36-04-E & 0.4 & 1.2 & 0.32 & 12.2 \\
\hline IC 36-04-F & 0.5 & 1.3 & 0.42 & 7.9 \\
\hline IC 36-04-G & 4.7 & 4.7 & 1.00 & 15.2 \\
\hline IC $36-04-\mathrm{H}$ & 4.8 & 4.8 & 1.00 & 14.7 \\
\hline IC 36-04-I & 4.8 & 4.8 & 1.00 & 8.2 \\
\hline IC 36-04-J & 3.9 & 3.9 & 1.00 & 11.1 \\
\hline IC 36-05-A & 0.7 & 3.4 & 0.20 & 24.5 \\
\hline IC $36-05-B$ & 0.5 & 3.4 & 0.14 & 19.9 \\
\hline IC $36-05-C$ & 0.6 & 2.3 & 0.28 & 15.9 \\
\hline IC 36-05-D & 0.8 & 2.0 & 0.42 & 7.5 \\
\hline IC 36-05-E & 2.1 & 2.7 & 0.80 & 11.8 \\
\hline IC 36-05-F & 3.0 & 3.0 & 1.00 & 17.4 \\
\hline IC $36-05-\mathrm{G}$ & 6.1 & 6.1 & 1.00 & 8.1 \\
\hline IC $36-05-\mathrm{H}$ & 4.5 & 4.5 & 1.00 & 10.9 \\
\hline IC 54-04-A & 1.6 & 7.9 & 0.20 & 37.6 \\
\hline IC 54-04-B & 6.8 & 12.5 & 0.54 & 43.3 \\
\hline IC 54-04-C & 0.5 & 7.0 & 0.07 & 49.6 \\
\hline IC 54-04-D & 0.6 & 1.4 & 0.42 & 26.0 \\
\hline IC 54-04-E & 1.8 & 2.1 & 0.83 & 8.4 \\
\hline IC 54-04-F & 2.1 & 2.3 & 0.92 & 8.4 \\
\hline IC 54-04-G & 2.3 & 2.5 & 0.93 & 8.4 \\
\hline IC 54-04-H & 3.0 & 3.2 & 0.94 & 11.5 \\
\hline IC 54-04-I & 19.0 & 18.8 & 1.01 & 20.6 \\
\hline
\end{tabular}


Appendix 4. Concentration of iron sequentially extracted from the sediment samples-Continued.

\begin{tabular}{|c|c|c|c|c|}
\hline Sample Number & $\begin{array}{c}\mathrm{Fe}^{2+} \\
0.5 \mathrm{~N} \mathrm{HCl} \\
\left(\mu \mathrm{mole} \mathrm{g}^{-1}\right)\end{array}$ & $\begin{array}{c}\mathrm{Fe}_{\text {total }} \\
0.5 \mathrm{~N} \mathrm{HCl} \\
\left(\mu \mathrm{mole} \mathrm{g}^{-1}\right)\end{array}$ & $\begin{array}{l}\mathrm{Fe}^{2+} / \mathrm{Fe}_{\text {total }} \\
0.5 \mathrm{~N} \mathrm{HCI}\end{array}$ & $\begin{array}{c}\text { Fe } \\
\mathrm{Ti}^{3+} \text {-EDTA } \\
\left(\mu \text { mole g }^{-1}\right)\end{array}$ \\
\hline IC 54-05-A & 1.2 & 6.1 & 0.20 & 34.0 \\
\hline IC 54-05-B & 9.8 & 15.0 & 0.66 & 45.7 \\
\hline IC 54-05-C & 1.3 & 4.5 & 0.28 & 33.3 \\
\hline IC 54-05-D & 0.7 & 2.7 & 0.28 & 6.8 \\
\hline IC 54-05-E & 0.5 & 1.7 & 0.28 & 6.4 \\
\hline IC 54-05-F & 1.0 & 2.1 & 0.45 & 6.1 \\
\hline IC $54-05-G$ & 2.9 & 3.0 & 0.94 & 5.7 \\
\hline IC $54-05-\mathrm{H}$ & 3.0 & 3.0 & 1.00 & 10.2 \\
\hline IC South-04-A & 0.6 & 3.4 & 0.19 & 29.2 \\
\hline IC South-04-B & 0.4 & 7.2 & 0.06 & 27.4 \\
\hline IC South-04-C & 6.4 & 9.8 & 0.65 & 29.2 \\
\hline IC South-04-D & 1.0 & 3.6 & 0.29 & 22.9 \\
\hline IC South-04-E & 4.5 & 4.7 & 0.96 & 22.7 \\
\hline IC South-04-F & 3.8 & 3.9 & 0.95 & 21.1 \\
\hline IC South-04-G & 2.9 & 3.2 & 0.89 & 20.2 \\
\hline IC South-04-H & 3.0 & 3.4 & 0.89 & 17.5 \\
\hline IC South-04-I & 3.0 & 3.2 & 0.94 & 12.5 \\
\hline IC South-04-J & 3.0 & 3.0 & 1.00 & 9.0 \\
\hline IC South-04-K & 2.3 & 2.3 & 1.00 & 7.9 \\
\hline IC South-04-L & 7.7 & 7.7 & 1.00 & 22.6 \\
\hline IC South-05-A & 2.0 & 4.5 & 0.44 & 20.8 \\
\hline IC South-05-B & 1.6 & 3.4 & 0.47 & 24.7 \\
\hline IC South-05-C & 4.7 & 5.0 & 0.93 & 23.3 \\
\hline IC South-05-D & 4.7 & 4.8 & 0.96 & 23.3 \\
\hline IC South-05-E & 4.8 & 5.2 & 0.93 & 19.3 \\
\hline
\end{tabular}


Appendix 5. Concentrations of water-soluble sulfate sulfur, acid-soluble sulfate sulfur, acid-volatile sulfide and disulfide sulfur extracted from the sediment samples and their sulfur isotope composition $\left(\delta^{34} \mathrm{~S}\right)$. Recovered water-soluble sulfate was insufficient for isotope analyses. Acid-soluble sulfate extracted with hot $6 \mathrm{~N} \mathrm{HCl}$. Concentrations were calculated on an air-dried sediment basis.

[nd, not determined; sulfate-HCl, acid-soluble sulfate; AVS, acid-volatile sulfide; DI, disulfide sulfur]

\begin{tabular}{|c|c|c|c|c|c|c|c|}
\hline Sample Number & $\begin{array}{c}\text { Sulfate- } \\
\text { Sulfur } \mathrm{H}_{2} \mathbf{0} \\
\left(\mu \text { mole } \mathbf{g}^{-1}\right)\end{array}$ & $\begin{array}{c}\text { Sulfate- } \\
\text { Sulfur } \\
6 N \text { HCI } \\
\left(\mu \text { mole g }^{-1}\right)\end{array}$ & $\begin{array}{c}\text { AVS } \\
\left(\mu \text { mole g }{ }^{-1}\right)\end{array}$ & $\begin{array}{c}\text { DI } \\
\left(\mu \text { mole g }^{-1}\right)\end{array}$ & $\begin{array}{l}\delta^{34} S_{\text {suffate-fcl }} \\
\text { (per mil) }\end{array}$ & $\begin{array}{c}\delta^{34} S_{\text {Avs }} \\
\text { (per mil) }\end{array}$ & $\begin{array}{c}\delta^{34} S_{01} \\
\text { (per mil) }\end{array}$ \\
\hline IC $36-04-\mathrm{A}$ & 0.2 & 1.0 & 0.1 & $<0.1$ & 10 & nd & nd \\
\hline IC 36-04-B & $<0.2$ & 0.5 & 0.1 & $<0.1$ & 9.6 & nd & nd \\
\hline IC 36-04-C & $<0.2$ & 0.8 & $<0.1$ & $<0.1$ & 10.2 & nd & nd \\
\hline IC 36-04-D & $<0.2$ & 0.7 & $<0.1$ & $<0.1$ & 11.4 & nd & nd \\
\hline IC 36-04-E & 0.2 & 0.8 & $<0.1$ & $<0.1$ & 11.6 & nd & nd \\
\hline IC 36-04-F & $<0.2$ & 0.7 & $<0.1$ & 0.1 & 12.7 & nd & nd \\
\hline IC 36-04-G & $<0.2$ & 0.7 & 1.7 & 2.2 & 13.3 & -16.8 & -24.0 \\
\hline IC 36-04-H & $<0.2$ & 0.6 & 2.8 & 1.2 & 15 & -8.8 & -19.3 \\
\hline IC 36-04-I & $<0.2$ & 0.7 & 1.7 & 0.6 & 13.7 & -3.9 & -19.1 \\
\hline IC 36-04-J & $<0.2$ & 0.6 & 0.6 & 0.5 & 11 & -13.6 & -17.7 \\
\hline IC 36-05-A & nd & 0.2 & $<0.1$ & $<0.1$ & 7.6 & nd & nd \\
\hline IC $36-05-B$ & nd & 0.5 & $<0.1$ & $<0.1$ & 10.6 & nd & nd \\
\hline IC $36-05-\mathrm{C}$ & nd & 0.4 & $<0.1$ & $<0.1$ & 12.1 & nd & nd \\
\hline IC 36-05-D & nd & 0.8 & $<0.1$ & 0.2 & 15.2 & nd & nd \\
\hline IC 36-05-E & nd & 0.7 & 0.7 & 1.2 & 14.9 & -16.3 & -16 \\
\hline IC $36-05-F$ & nd & 1.0 & 2.3 & 5.5 & 14.7 & -18.5 & -25.1 \\
\hline IC $36-05-G$ & nd & 0.6 & 2.8 & 1.1 & 15.1 & -7.6 & -21.5 \\
\hline IC $36-05-\mathrm{H}$ & nd & 0.2 & 1.3 & 0.7 & nd & -4.9 & -13.3 \\
\hline IC 54-04-A & 0.2 & 1.6 & 0.2 & 1.2 & 4 & nd & -9.1 \\
\hline IC 54-04-B & 70.2 & 2.4 & 0.2 & $<0.1$ & 7.3 & nd & nd \\
\hline IC 54-04-C & 70.2 & 1.7 & 0.1 & $<0.1$ & 6.5 & nd & nd \\
\hline IC 54-04-D & 0.3 & 0.7 & $<0.1$ & 0.1 & 14.8 & nd & nd \\
\hline IC 54-04-E & $<0.2$ & 0.4 & 0.6 & 0.2 & 14.1 & -15.0 & nd \\
\hline IC 54-04-F & $<0.2$ & 0.4 & 0.8 & 0.2 & 15.8 & -13.1 & -18.8 \\
\hline IC 54-04-G & $<0.2$ & 0.7 & 0.4 & 0.3 & 20.1 & -12.0 & nd \\
\hline
\end{tabular}


Appendix 5. Concentrations and isotopic composition of sulfur species-Continued.

\begin{tabular}{|c|c|c|c|c|c|c|c|}
\hline Sample Number & $\begin{array}{c}\text { Sulfate- } \\
\text { Sulfur } \mathrm{H}_{2} \mathbf{0} \\
\left(\mu \text { mole g }^{-1}\right)\end{array}$ & $\begin{array}{c}\text { Sulfate- } \\
\text { Sulfur } \\
\text { 6N HCI } \\
\left(\mu \text { mole g }^{-1}\right)\end{array}$ & $\begin{array}{c}\text { AVS } \\
\left(\mu \text { mole g }^{-1}\right)\end{array}$ & $\left.\begin{array}{c}\text { DI } \\
(\mu \text { mole g } \\
-1\end{array}\right)$ & $\begin{array}{l}\delta^{34} S_{\text {sulfate-fcl }} \\
\text { (per mil) }\end{array}$ & $\begin{array}{c}\delta^{34} S_{\text {Avs }} \\
\text { (per mil) }\end{array}$ & $\begin{array}{c}\delta^{34} S_{01} \\
\text { (per mil) }\end{array}$ \\
\hline IC 54-04-H & $<0.2$ & 0.7 & 0.9 & 0.4 & 19.0 & -11.2 & -15.9 \\
\hline IC 54-04-I & 0.5 & 1.9 & 3.8 & 15.0 & 10.8 & 4.3 & 3.6 \\
\hline IC 54-05-A & nd & 1.4 & 0.1 & 0.1 & nd & nd & nd \\
\hline IC 54-05-B & nd & 0.5 & $<0.1$ & 0.1 & nd & nd & nd \\
\hline IC 54-05-C & nd & 0.3 & $<0.1$ & 0.1 & nd & nd & nd \\
\hline IC 54-05-D & nd & 0.4 & 0.1 & $<0.1$ & 12.8 & nd & nd \\
\hline IC 54-05-E & nd & 0.5 & $<0.1$ & $<0.1$ & 13.7 & nd & nd \\
\hline IC $54-05-F$ & nd & 0.8 & 0.1 & $<0.1$ & 13.6 & nd & nd \\
\hline IC $54-05-\mathrm{G}$ & nd & 0.5 & 0.5 & 0.3 & 18.1 & -12.4 & -16.4 \\
\hline IC 54-05-H & nd & 0.6 & 1.1 & 1.1 & 11.3 & -2 & 2.7 \\
\hline IC South-04-A & $<0.2$ & 0.8 & $<0.1$ & 0.2 & 7.0 & nd & -16 \\
\hline IC South-04-B & $<0.2$ & 1.1 & $<0.1$ & 0.1 & 6.2 & nd & nd \\
\hline IC South-04-C & 0.2 & 1.3 & 0.4 & 0.5 & 5.5 & -18.5 & -19.7 \\
\hline IC South-04-D & $<0.2$ & 0.8 & 0.1 & 0.1 & 6.8 & nd & nd \\
\hline IC South-04-E & 0.2 & 0.8 & 0.5 & 0.3 & 5.7 & -14.4 & -18.8 \\
\hline IC South-04-F & 0.2 & 0.9 & 0.4 & 0.6 & 5.5 & -15.4 & -22.4 \\
\hline IC South-04-G & $<0.2$ & 0.6 & 0.6 & 0.4 & 7.3 & -17.8 & -17.4 \\
\hline IC South-04-H & $<0.2$ & 0.7 & 0.6 & 0.4 & 9.7 & -21.5 & -15.4 \\
\hline IC South-04-I & $<0.2$ & 0.8 & 0.7 & 0.5 & 10.2 & -17.8 & -20.3 \\
\hline IC South-04-J & $<0.2$ & 1.4 & 2.4 & 1.4 & 9.5 & -7.1 & -16 \\
\hline IC South-04-K & $<0.2$ & 0.9 & 1.5 & 0.3 & 12.4 & -7.8 & -12 \\
\hline IC South-04-L & $<0.2$ & 1.2 & 2.1 & 2.0 & 11.4 & -7.1 & -13.3 \\
\hline IC South-05-A & nd & 0.8 & 0.1 & 0.2 & 7.3 & nd & -17 \\
\hline IC South-05-B & nd & 0.7 & 0.2 & 0.3 & 7.2 & nd & -19.7 \\
\hline IC South-05-C & nd & 0.8 & 0.8 & 0.6 & 7.1 & -13.3 & -22.1 \\
\hline IC South-05-D & nd & 0.8 & 0.5 & 0.3 & 6.6 & -18.4 & -23.5 \\
\hline IC South-05-E & nd & 0.6 & 0.6 & 0.5 & 6.8 & -17.4 & -19.9 \\
\hline
\end{tabular}


Appendix 6. Results of chemical and isotopic analyses of ground water samples from wells at IC 36, IC 54, and IC South.

[nd, not determined; S.Cond., specific conductance; $\mu \mathrm{S} / \mathrm{cm}$, microSiemens per centimeter; DOC, dissolved organic carbon; mg/L, milligrams per liter]

\begin{tabular}{|c|c|c|c|c|c|c|c|c|c|c|}
\hline Well & $\begin{array}{c}\text { Sample } \\
\text { Date }\end{array}$ & $\begin{array}{c}\text { Elevation of Well } \\
\text { Screen Center }\end{array}$ & $\mathrm{pH}$ & $\begin{array}{l}\text { S. Cond. } \\
(\mu \mathrm{S} / \mathrm{cm})\end{array}$ & $\begin{array}{c}\mathrm{Ca} \\
(\mathrm{mg} / \mathrm{L})\end{array}$ & $\begin{array}{c}\mathrm{Mg} \\
(\mathrm{mg} / \mathrm{L}) \\
\end{array}$ & $\begin{array}{c}\mathrm{K} \\
(\mathrm{mg} / \mathrm{L}) \\
\end{array}$ & $\begin{array}{c}\mathrm{Na} \\
(\mathrm{mg} / \mathrm{L})\end{array}$ & $\begin{array}{c}\mathrm{Fe} \\
(\mathrm{mg} / \mathrm{L})\end{array}$ & $\begin{array}{c}\mathrm{NH}_{4}^{+} \\
(\mathrm{mg} / \mathrm{L}) \\
\end{array}$ \\
\hline IC $36-5$ & 13-Oct-04 & 329.995 & 7.40 & 760 & 91.8 & 12 & 47 & 29 & 0.61 & 4.8 \\
\hline IC $36-6$ & 13-Oct-04 & 329.870 & 7.27 & 1040 & 67.2 & 18 & 0.6 & 0.60 & nd & 52 \\
\hline IC $36-7$ & 13-Oct-04 & 329.730 & 7.33 & 1410 & 81.8 & 30 & 87 & 92 & 3.1 & 64 \\
\hline IC 36-8 & 13-Oct-04 & 329.605 & 7.34 & 2330 & 238 & 89 & 108 & 245 & 12.3 & 31 \\
\hline IC 36-9 & $13-$ Oct-04 & 329.450 & 7.22 & 2330 & 134 & 66 & 151 & 292 & 2.9 & 17 \\
\hline IC $36-10$ & 13-Oct-04 & 329.320 & 7.20 & 3350 & 90.2 & 48 & 188 & 303 & nd & 50 \\
\hline IC $36-11$ & 13-Oct-04 & 329.200 & 7.01 & 3350 & 84.2 & 54 & 213 & 354 & nd & 46 \\
\hline IC $36-12$ & 13-Oct-04 & 329.060 & 7.02 & 4340 & 87.8 & 63 & 228 & 395 & nd & 294 \\
\hline IC $36-13$ & 13-Oct-04 & 328.920 & 7.06 & 4660 & 90.0 & 66 & 189 & 371 & nd & 138 \\
\hline IC $36-14$ & 13-Oct-04 & 328.785 & 6.98 & 4800 & 130 & 86 & 208 & 473 & nd & 169 \\
\hline IC $36-15$ & 13-Oct-04 & 328.655 & 7.02 & 4653 & 133 & 78 & 153 & 437 & nd & 335 \\
\hline IC $36-16$ & 13-Oct-04 & 328.520 & 7.03 & 4630 & 164 & 95 & 172 & 531 & 14.5 & 361 \\
\hline IC $36-17$ & 13-Oct-04 & 328.385 & 7.02 & 4570 & nd & nd & nd & nd & nd & 289 \\
\hline IC 36-3 & 19-Apr-05 & 330.260 & 7.28 & 584 & 86.6 & 7.4 & 13 & 19 & 0.09 & $<0.7$ \\
\hline IC 36-4 & 19-Apr-05 & 330.130 & 7.28 & 584 & 106 & 14.1 & 21 & 22 & 0.22 & 2.10 \\
\hline IC 36-5 & 19-Apr-05 & 329.995 & 7.07 & 928 & 125 & 23 & 28 & 38 & 1.7 & 2.6 \\
\hline IC 36-6 & 19-Apr-05 & 329.995 & 7.07 & 928 & 176 & 48 & 51 & 99 & 7.8 & 2.0 \\
\hline IC 36-7 & 19-Apr-05 & 329.730 & 7.07 & 928 & 219 & 70 & 82 & 170 & 9.8 & 17 \\
\hline IC 36-8 & 19-Apr-05 & 329.605 & 7.07 & 3104 & 238 & 89 & 108 & 245 & 12.3 & 63 \\
\hline IC 36-9 & 19-Apr-05 & 329.450 & 7.08 & 2826 & 202 & 83 & 142 & 273 & 4.1 & 88 \\
\hline IC $36-10$ & 19-Apr-05 & 329.320 & 6.78 & 3691 & 171 & 73 & 182 & 352 & 5.0 & 148 \\
\hline IC 36-11 & 19-Apr-05 & 329.200 & 7.23 & 4068 & 120 & 54 & 200 & 379 & 6.2 & 206 \\
\hline IC $36-12$ & 19-Apr-05 & 329.060 & 7.49 & 4424 & 108 & 59 & 229 & 466 & 8.6 & 186 \\
\hline IC $36-13$ & 19-Apr-05 & 328.920 & 7.10 & 4313 & 82.0 & 57 & 198 & 472 & 10.9 & 192 \\
\hline
\end{tabular}


Appendix 6. Results of chemical and isotopic analyses of ground water samples from wells-Continued.

\begin{tabular}{|c|c|c|c|c|c|c|c|c|}
\hline $\begin{array}{c}\text { Well } \\
\text { Sampled }\end{array}$ & $\begin{array}{c}\text { DOC } \\
\text { (mg/L) }\end{array}$ & $\begin{array}{l}\mathrm{HCO}_{3}^{-} \\
\mathrm{mg} / \mathrm{L}^{-}\end{array}$ & $\begin{array}{c}\mathrm{Cl}^{-} \\
(\mathrm{mg} / \mathrm{L})\end{array}$ & $\begin{array}{c}\mathrm{SO}_{4}^{2-} \\
(\mathrm{mg} / \mathrm{L})\end{array}$ & $\begin{array}{c}\delta^{18} \mathbf{O}_{\text {s04 }} \\
\text { (per mil) }\end{array}$ & $\begin{array}{c}\delta^{34} \mathrm{~S}_{\mathrm{s04}} \\
\text { (per mil) }\end{array}$ & $\begin{array}{c}\delta^{18} \mathbf{O}_{\mathrm{H} 20} \\
\text { (per mil) }\end{array}$ & $\begin{array}{c}\delta^{2} H_{\mathrm{H} 20} \\
\text { (per mil) }\end{array}$ \\
\hline IC 36-5 & nd & nd & 21 & 50 & 6.6 & 10.7 & -5.66 & -34.70 \\
\hline IC 36-6 & 9.4 & nd & 43 & 25 & 13.6 & 36.0 & -5.83 & -34.00 \\
\hline IC 36-7 & 16 & nd & 90 & 42 & 15.0 & 43.0 & -5.94 & -33.20 \\
\hline IC 36-8 & 29 & nd & 130 & 67 & 16.6 & 38.9 & -6.04 & -31.30 \\
\hline IC 36-9 & 49 & nd & 210 & 78 & 16.5 & 36.5 & -5.98 & -27.90 \\
\hline IC $36-10$ & 57 & nd & 230 & 24 & 17.6 & 41.3 & -5.89 & -26.70 \\
\hline IC $36-11$ & 69 & nd & 270 & 7.9 & nd & nd & -5.84 & -23.00 \\
\hline IC $36-12$ & 80 & nd & 340 & 1.4 & nd & nd & -5.71 & -20.80 \\
\hline IC $36-13$ & 86 & nd & 360 & 0.5 & nd & nd & -5.74 & -19.20 \\
\hline IC $36-14$ & 92 & nd & 390 & 0.6 & nd & nd & -5.62 & -17.00 \\
\hline IC $36-15$ & 88 & nd & 400 & 0.6 & nd & nd & -5.66 & -16.80 \\
\hline IC $36-16$ & 85 & nd & 400 & 0.8 & nd & nd & -5.63 & -18.50 \\
\hline IC $36-17$ & 82 & nd & 400 & 0.5 & nd & nd & -5.57 & -17.80 \\
\hline IC $36-3$ & 6.0 & 336.9 & 8.9 & 18.9 & nd & 14.7 & -6.96 & -41.30 \\
\hline IC $36-4$ & 16 & 442.9 & 18.4 & 16.9 & nd & 20.6 & -6.68 & -39.19 \\
\hline IC $36-5$ & 20 & 533.7 & 35.8 & 21 & nd & 27.4 & -6.84 & -39.02 \\
\hline IC $36-6$ & 11 & 1008 & 91.2 & 47 & nd & 29.8 & -7.12 & -41.30 \\
\hline IC 36-7 & 19 & 1417 & 143 & 60 & 15.2 & 30.1 & -6.96 & -36.03 \\
\hline IC $36-8$ & 18 & 1768 & 185 & 51 & 20.0 & 46.2 & -6.82 & -33.66 \\
\hline IC $36-9$ & 30 & 1897 & 203 & 38 & 18.5 & 50.4 & nd & nd \\
\hline IC $36-10$ & 50 & 2071 & 244 & 46 & 17.6 & 49.3 & -6.31 & -26.83 \\
\hline IC 36-11 & 55 & 2180 & 274 & 39 & 16.9 & 48.0 & -6.06 & -25.11 \\
\hline IC $36-12$ & 70 & 2332 & 329 & 15.2 & nd & nd & -5.81 & -21.18 \\
\hline IC $36-13$ & 80 & 2224 & 348 & 1.0 & nd & nd & -5.48 & -20.64 \\
\hline
\end{tabular}


Appendix 6. Results of chemical and isotopic analyses of ground water samples from wells-Continued.

\begin{tabular}{|c|c|c|c|c|c|c|c|c|c|c|}
\hline Well & $\begin{array}{c}\text { Sample } \\
\text { Date }\end{array}$ & $\begin{array}{c}\text { Elevation of Well } \\
\text { Screen Center }\end{array}$ & pH & $\begin{array}{l}\text { S. Cond. } \\
(\mu \text { S/cm) }\end{array}$ & $\begin{array}{c}\mathrm{Ca} \\
(\mathrm{mg} / \mathrm{L}) \\
\end{array}$ & $\begin{array}{c}\mathrm{Mg} \\
(\mathrm{mg} / \mathrm{L})\end{array}$ & $\begin{array}{c}K \\
(\mathrm{mg} / \mathrm{L}) \\
\end{array}$ & $\begin{array}{c}\mathrm{Na} \\
(\mathrm{mg} / \mathrm{L})\end{array}$ & $\begin{array}{c}\mathrm{Fe} \\
(\mathrm{mg} / \mathrm{L})\end{array}$ & $\begin{array}{c}\mathrm{NH}_{4}^{+} \\
(\mathrm{mg} / \mathrm{L})\end{array}$ \\
\hline IC 36-14 & 19-Apr-05 & 328.785 & 6.95 & 4030 & 82.7 & 56 & 166 & 447 & 10.8 & 226 \\
\hline IC $36-15$ & 19-Apr-05 & 328.655 & 7.10 & 3694 & 84.8 & 53 & 146 & 440 & 9.8 & 159 \\
\hline IC $36-16$ & 19-Apr-05 & 328.520 & 7.02 & 3639 & 87.4 & 51 & 135 & 425 & 9.4 & 141 \\
\hline IC $36-17$ & 19-Apr-05 & 328.385 & 6.97 & 3592 & 86.4 & 50 & 119 & 414 & 9.1 & 119 \\
\hline IC 54-4 & 14-Oct-04 & 329.765 & 7.10 & 1580 & 150 & 51 & 7.5 & 125 & 0.31 & 0.9 \\
\hline IC 54-5 & 14-Oct-04 & 329.615 & 7.15 & 1580 & 118 & 44 & 7.6 & 187 & 0.47 & 0.8 \\
\hline IC 54-6 & 14-Oct-04 & 329.460 & 7.24 & 1470 & 96 & 35 & 7.8 & 191 & nd & 0.7 \\
\hline IC 54-7 & 14-Oct-04 & 329.305 & 7.28 & 1160 & 76 & 28 & 7.2 & 130 & 0.59 & 2.0 \\
\hline IC 54-8 & 14-Oct-04 & 329.150 & 7.42 & nd & 67 & 28 & 7.2 & 138 & 1.7 & 4.3 \\
\hline IC 54-9 & 14-Oct-04 & 329.025 & 7.42 & 1120 & 54 & 24 & 6.7 & 181 & 1.2 & 4.3 \\
\hline IC $54-10$ & 14-Oct-04 & 328.875 & 7.70 & 1160 & 50 & 22 & 5.8 & 183 & 1.4 & 5.8 \\
\hline IC 54-11 & 14-Oct-04 & 328.720 & 7.70 & 1250 & 52 & 24 & 5.1 & 180 & 1.7 & 5.6 \\
\hline IC 54-12 & 14-Oct-04 & 328.565 & 7.50 & nd & 65 & 29 & 5.9 & 214 & 1.4 & 6.2 \\
\hline IC $54-13$ & 14-Oct-04 & 328.415 & 7.60 & 1290 & 58 & 26 & 4.8 & 194 & nd & 6.5 \\
\hline IC 54-14 & 14-Oct-04 & 328.265 & 7.50 & 1360 & 61 & 28 & 4.5 & 211 & nd & 6.6 \\
\hline IC 54-3 & 19-Apr-05 & 329.915 & 7.07 & 1580 & 168 & 44 & 9.1 & 77 & 0.27 & 1.1 \\
\hline IC 54-4 & 19-Apr-05 & 329.765 & 6.75 & 1322 & 159 & 48 & 5.8 & 77 & 0.93 & $<0.7$ \\
\hline IC 54-5 & 19-Apr-05 & 329.615 & 6.84 & 1471 & 159 & 55 & 6.4 & 113 & 4.5 & 2.1 \\
\hline IC 54-6 & 19-Apr-05 & 329.460 & 6.84 & 1539 & 146 & 51 & 8.0 & 160 & 7.8 & 0.6 \\
\hline IC 54-7 & 20-Apr-05 & 329.305 & 6.83 & 1426 & 96 & 35 & 6.3 & 168 & 4.8 & 0.6 \\
\hline IC 54-8 & 20-Apr-05 & 329.150 & 7.10 & 1410 & 87 & 34 & 6.8 & 197 & 3.8 & 0.7 \\
\hline IC 54-9 & 20-Apr-05 & 329.025 & 7.10 & 1442 & 83 & 33 & 6.7 & 207 & 2.2 & 0.7 \\
\hline IC 54-10 & 20-Apr-05 & 328.875 & 7.30 & 1586 & 91 & 37 & 6.3 & 238 & 2.4 & 2.8 \\
\hline IC 54-11 & 20-Apr-05 & 328.720 & 7.25 & 1696 & 103 & 42 & 6.0 & 262 & 2.2 & 4.0 \\
\hline
\end{tabular}


Appendix 6. Results of chemical and isotopic analyses of ground water samples from wells-Continued.

\begin{tabular}{|c|c|c|c|c|c|c|c|c|}
\hline $\begin{array}{c}\text { Well } \\
\text { Sampled }\end{array}$ & $\begin{array}{c}\text { DOC } \\
\text { (mg/L) }\end{array}$ & $\begin{array}{l}\mathrm{HCO}_{3}^{-} \\
\mathrm{mg} / \mathrm{L}^{-}\end{array}$ & $\begin{array}{c}\mathrm{Cl}^{-} \\
(\mathrm{mg} / \mathrm{L})\end{array}$ & $\begin{array}{c}\mathrm{SO}_{4}^{2-} \\
(\mathrm{mg} / \mathrm{L})\end{array}$ & $\begin{array}{c}\delta^{18} \mathbf{O}_{\text {s04 }} \\
\text { (per mil) }\end{array}$ & $\begin{array}{c}\delta^{34} \mathbf{S}_{\text {s04 }} \\
\text { (per mil) }\end{array}$ & $\begin{array}{c}\delta^{18} \mathbf{O}_{\mathrm{H} 20} \\
\text { (per mil) }\end{array}$ & $\begin{array}{c}\delta^{2} H_{\mathrm{H} 20} \\
\text { (per mil) }\end{array}$ \\
\hline IC $36-14$ & 90 & 2037 & 328 & 0.2 & nd & nd & -5.31 & -20.94 \\
\hline IC $36-15$ & 88 & 1886 & 314 & 0.5 & nd & nd & -5.17 & -20.88 \\
\hline IC $36-16$ & 82 & 1851 & 300 & 0.5 & nd & nd & -5.02 & -19.72 \\
\hline IC $36-17$ & 81 & 1840 & 306 & 0.5 & nd & nd & -5.09 & -20.90 \\
\hline IC 54-4 & 6.6 & nd & 84 & 98 & 13.9 & 15.6 & -3.80 & -22.80 \\
\hline IC 54-5 & 9.8 & nd & 94 & 117 & nd & nd & -3.43 & -21.20 \\
\hline IC 54-6 & 15 & nd & 89 & 87 & 16.0 & 26.4 & -3.24 & -21.80 \\
\hline IC 54-7 & 19 & nd & 68 & 25 & nd & nd & -3.05 & -19.60 \\
\hline IC 54-8 & 32 & nd & 64 & 8.6 & 18.6 & 42.9 & -2.78 & -18.50 \\
\hline IC 54-9 & 21 & nd & 63 & 7.7 & nd & nd & -4.04 & -18.21 \\
\hline IC $54-10$ & 22 & nd & 64 & 10.6 & 21.4 & 61.5 & -3.02 & -19.20 \\
\hline IC 54-11 & 25 & nd & 73 & 21 & nd & nd & -2.56 & -16.50 \\
\hline IC $54-12$ & 25 & nd & 75 & 15.1 & 22.0 & 65.7 & -2.49 & -17.50 \\
\hline IC 54-13 & 25 & nd & 73 & 1.6 & nd & nd & -2.62 & -18.20 \\
\hline IC 54-14 & 24 & nd & 82 & 1.0 & nd & nd & -2.89 & -19.20 \\
\hline IC 54-3 & 2.1 & 813 & 41 & 27 & nd & 49.4 & -5.36 & -32.88 \\
\hline IC 54-4 & 5.4 & 820 & 43 & 33 & nd & 14.2 & -5.21 & -31.79 \\
\hline IC 54-5 & 20 & 870 & 65 & 57 & nd & 18.4 & -4.62 & -28.57 \\
\hline IC 54-6 & 13 & 858 & 74 & 61 & nd & 24.8 & -3.91 & -24.13 \\
\hline IC 54-7 & 16 & 766 & 81 & 40 & nd & nd & -3.26 & -21.17 \\
\hline IC 54-8 & 27 & 765 & 86 & 26 & nd & nd & -2.90 & -19.96 \\
\hline IC 54-9 & 14 & 812 & 87 & 16.5 & nd & nd & -2.44 & -17.32 \\
\hline IC 54-10 & 17 & 883 & 110 & 21 & nd & 74.1 & -1.70 & -14.29 \\
\hline IC 54-11 & 17 & 807 & 130 & 27 & nd & nd & -1.27 & -9.2 \\
\hline
\end{tabular}


Appendix 6. Results of chemical and isotopic analyses of ground water samples from wells-Continued.

\begin{tabular}{|c|c|c|c|c|c|c|c|c|c|c|}
\hline Well & $\begin{array}{c}\text { Sample } \\
\text { Date }\end{array}$ & $\begin{array}{l}\text { Elevation of Well } \\
\text { Screen Center }\end{array}$ & pH & $\begin{array}{l}\text { S. Cond. } \\
(\mu \mathrm{S} / \mathrm{cm})\end{array}$ & $\begin{array}{c}\mathrm{Ca} \\
\text { (mg/L) }\end{array}$ & $\begin{array}{c}\mathrm{Mg} \\
\text { (mg/L) }\end{array}$ & K (mg/L) & $\begin{array}{c}\mathrm{Na} \\
(\mathrm{mg} / \mathrm{L})\end{array}$ & $\begin{array}{c}\mathrm{Fe} \\
(\mathrm{mg} / \mathrm{L})\end{array}$ & $\begin{array}{c}\mathrm{NH}_{4}^{+} \\
(\mathrm{mg} / \mathrm{L})\end{array}$ \\
\hline IC $54-12$ & 20-Apr-05 & 328.565 & 7.23 & 1822 & 105 & 43 & 5.8 & 272 & 2.0 & 6.1 \\
\hline IC $54-13$ & $20-A p r-05$ & 328.415 & 7.28 & 2032 & 118 & 49 & 5.3 & 280 & 4.4 & 8.6 \\
\hline IC 54-14 & 20-Apr-05 & 328.265 & 6.87 & 2368 & 144 & 59 & 5.6 & 309 & 7.0 & 8.6 \\
\hline IC South-3 & $14-O c t-04$ & 329.655 & 7.80 & 797 & 144 & 11 & 2.1 & 5.6 & 0.51 & 0.7 \\
\hline IC South-4 & $14-O c t-04$ & 329.505 & 7.20 & 928 & 200 & 13 & 2.4 & 6.4 & 0.28 & 1.5 \\
\hline IC South-5 & $14-O c t-04$ & 329.355 & 7.20 & 907 & 182 & 13 & 3.1 & 8.1 & 0.29 & $<0.7$ \\
\hline IC South-6 & $14-O c t-04$ & 329.195 & 7.20 & 913 & 183 & 16 & 4.2 & 11 & 1.1 & 1.3 \\
\hline IC South-7 & 14-Oct-04 & 329.035 & 7.10 & 979 & 201 & 20 & 5.1 & 13 & 8.6 & 0.9 \\
\hline IC South-8 & $14-O c t-04$ & 328.895 & 7.21 & 1010 & 170 & 19 & 4.9 & 12 & 5.7 & 3.3 \\
\hline IC South-9 & 14-Oct-04 & 328.765 & 7.20 & 993 & 161 & 19 & 4.8 & 14 & 6.4 & 3.6 \\
\hline IC South-10 & $14-O c t-04$ & 328.595 & 7.20 & 930 & 141 & 20 & 4.9 & 23 & 5.9 & 3.6 \\
\hline IC South-11 & 14-Oct-04 & 328.445 & 7.30 & 972 & 141 & 23 & 5.2 & 42 & 5.4 & 2.6 \\
\hline IC South-12 & $14-O c t-04$ & 328.295 & 7.35 & 1140 & 142 & 32 & 5.2 & 66 & 3.7 & 5.4 \\
\hline IC South-13 & 14-Oct-04 & 328.145 & 7.40 & 1210 & 128 & 35 & 4.8 & 74 & 2.6 & 5.0 \\
\hline IC South-14 & $14-O c t-04$ & 327.995 & 7.40 & 1320 & 142 & 40 & 4.9 & 99 & nd & 4.6 \\
\hline IC South-3 & 20-Apr-05 & 329.655 & 7.50 & 800 & 104 & 12 & 2.1 & 17.2 & 0.64 & $<0.7$ \\
\hline IC South-4 & $20-A p r-05$ & 329.655 & 6.63 & 628 & 123 & 8.1 & 1.3 & 5.4 & 0.02 & $<0.7$ \\
\hline IC South-5 & $20-A p r-05$ & 329.355 & 6.63 & 676 & 138 & 11 & 1.7 & 6.7 & 0.03 & $<0.7$ \\
\hline IC South-6 & $20-A p r-05$ & 329.195 & 6.71 & 781 & 154 & 14 & 2.7 & 8.4 & 0.64 & 2.5 \\
\hline IC South-7 & $20-A p r-05$ & 329.035 & 6.58 & 888 & 178 & 17 & 3.7 & 11 & 3.6 & $<0.7$ \\
\hline IC South-8 & $20-A p r-05$ & 328.895 & 6.75 & 922 & 185 & 19 & 4.0 & 13 & 5.3 & 3.2 \\
\hline IC South-9 & $20-A p r-05$ & 328.765 & 6.78 & 918 & 181 & 19 & 4.1 & 14 & 4.0 & 1.0 \\
\hline IC South-10 & $20-A p r-05$ & 328.595 & 6.81 & 934 & 153 & 19 & 4.0 & 25 & 5.7 & 1.2 \\
\hline IC South-11 & 20-Apr-05 & 328.445 & 6.61 & 1082 & 158 & 24 & 4.5 & 52 & 6.9 & $<0.7$ \\
\hline
\end{tabular}


Appendix 6. Results of chemical and isotopic analyses of ground water samples from wells-Continued.

\begin{tabular}{|c|c|c|c|c|c|c|c|c|}
\hline $\begin{array}{c}\text { Well } \\
\text { Sampled }\end{array}$ & $\begin{array}{c}\text { DOC } \\
\text { (mg/L) }\end{array}$ & $\begin{array}{l}\mathrm{HCO}_{3}^{-} \\
\mathrm{mg} / \mathrm{L}\end{array}$ & $\begin{array}{c}\mathrm{Cl}^{-} \\
(\mathrm{mg} / \mathrm{L})\end{array}$ & $\begin{array}{c}\mathrm{SO}_{4}^{2-} \\
(\mathrm{mg} / \mathrm{L})\end{array}$ & $\begin{array}{c}\delta^{18} \mathbf{0}_{\text {so4 }} \\
\text { (per mil) }\end{array}$ & $\begin{array}{c}\delta^{34} S_{\text {so4 }} \\
\text { (per mil) }\end{array}$ & $\begin{array}{c}\delta^{18} \mathbf{O}_{\mathrm{H} 20} \\
\text { (per mil) }\end{array}$ & $\begin{array}{c}\delta^{2} H_{\mathrm{H} 20} \\
\text { (per mil) }\end{array}$ \\
\hline IC 54-12 & 26 & 969 & 160 & 7.9 & 20.2 & 62.1 & -1.09 & -8.28 \\
\hline IC 54-13 & 20 & 1030 & 210 & 1.1 & nd & nd & -1.60 & -8.75 \\
\hline IC 54-14 & 24 & 1160 & 260 & 0.2 & $\mathrm{nd}$ & nd & -2.14 & -10.55 \\
\hline IC South-3 & 7.3 & nd & 1.3 & 27 & nd & nd & -5.19 & -33.00 \\
\hline IC South-4 & 7.2 & nd & 0.3 & 22 & 12.0 & -6.88 & -5.18 & -30.60 \\
\hline IC South-5 & 10 & nd & 0.3 & 48 & nd & nd & -5.30 & -31.10 \\
\hline IC South-6 & nd & nd & 0.7 & 96 & 14.0 & -5.9 & -5.36 & -31.60 \\
\hline IC South-7 & 7.3 & nd & 0.9 & 130 & nd & nd & -5.41 & -30.70 \\
\hline IC South-8 & 5.9 & nd & 1.4 & 127 & 13.5 & -4.8 & -5.38 & -29.80 \\
\hline IC South-9 & 6.5 & nd & 2.3 & 99 & nd & nd & -5.20 & -28.70 \\
\hline IC South-10 & 6.8 & nd & 12.6 & 42 & 18.0 & 11.1 & -5.07 & -25.70 \\
\hline IC South-11 & 7.0 & nd & 22 & 22 & nd & nd & -4.88 & -26.80 \\
\hline IC South-12 & 4.6 & nd & 53 & 9.7 & 18.1 & 31.3 & -4.55 & -25.00 \\
\hline IC South-13 & 11 & nd & 65 & 23 & nd & nd & -4.28 & -24.30 \\
\hline IC South-14 & 9.2 & nd & 78 & 23 & 20.5 & 40.1 & -4.01 & -23.00 \\
\hline IC South-3 & 4.9 & 278 & 8.5 & 14.8 & nd & 14.7 & -6.09 & -39.50 \\
\hline IC South-4 & 2.8 & 414 & 2.4 & 14.5 & nd & nd & -5.59 & -34.24 \\
\hline IC South-5 & 7.6 & 432 & 2.1 & 36 & nd & nd & -5.28 & -32.58 \\
\hline IC South-6 & 3.4 & 482 & 2.3 & 60 & nd & nd & -5.37 & -32.85 \\
\hline IC South-7 & 1.3 & 550 & 3.5 & 80 & 14.5 & -1.3 & -5.41 & -33.05 \\
\hline IC South-8 & 3.7 & 586 & 6.0 & 68 & 15.3 & 31.8 & -5.42 & -31.75 \\
\hline IC South-9 & 1.1 & 581 & 8.7 & 54 & nd & nd & -5.33 & -29.99 \\
\hline IC South-10 & 1.6 & 575 & 31 & 23 & nd & nd & -5.12 & -28.28 \\
\hline IC South-11 & 4.9 & 638 & 60 & 9.3 & nd & nd & -4.54 & -25.48 \\
\hline
\end{tabular}


Appendix 6. Results of chemical and isotopic analyses of ground water samples from wells-Continued.

\begin{tabular}{ccccccccccc}
\hline Well & $\begin{array}{c}\text { Sample } \\
\text { Date }\end{array}$ & $\begin{array}{c}\text { Elevation of Well } \\
\text { Screen Center }\end{array}$ & $\mathbf{p H}$ & $\begin{array}{c}\mathbf{S} \text {. Cond. } \\
(\boldsymbol{\mu} \mathbf{S} / \mathbf{c m})\end{array}$ & $\begin{array}{c}\mathbf{C a} \\
(\mathbf{m g} / \mathbf{L})\end{array}$ & $\begin{array}{c}\mathbf{M g} \\
(\mathbf{m g} / \mathbf{L})\end{array}$ & $\mathbf{K}(\mathbf{m g} / \mathbf{L})$ & $\begin{array}{c}\mathbf{N a} \\
(\mathbf{m g} / \mathbf{L})\end{array}$ & $\begin{array}{c}\mathbf{F e} \\
(\mathbf{m g} / \mathbf{L})\end{array}$ & $\begin{array}{c}\mathbf{N H} \\
(\mathbf{m g} / \mathbf{L})\end{array}$ \\
\hline IC South-12 & 20-Apr-05 & 328.295 & 6.07 & 1343 & 169 & 31 & 4.6 & 67 & 6.1 & 1.3 \\
IC South-13 & 20-Apr-05 & 328.145 & 6.62 & 1412 & 173 & 44 & 4.5 & 102 & 2.8 & $<0.7$ \\
IC South-14 & 20-Apr-05 & 327.995 & 6.97 & 1507 & 167 & 45 & 4.1 & 110 & 1.4 & 1.9 \\
\hline
\end{tabular}


Appendix 6. Results of chemical and isotopic analyses of ground water samples from wells-Continued.

\begin{tabular}{|c|c|c|c|c|c|c|c|c|}
\hline $\begin{array}{c}\text { Well } \\
\text { Sampled }\end{array}$ & $\begin{array}{c}\text { DOC } \\
\text { (mg/L) }\end{array}$ & $\begin{array}{l}\mathrm{HCO}_{3} \\
\mathrm{mg} / \mathrm{L}\end{array}$ & $\begin{array}{c}\mathrm{Cl}^{-} \\
(\mathrm{mg} / \mathrm{L})\end{array}$ & $\begin{array}{c}\mathrm{SO}_{4}^{2-} \\
(\mathrm{mg} / \mathrm{L})\end{array}$ & $\begin{array}{c}\delta^{18} 0_{\text {so4 }} \\
\text { (per mil) }\end{array}$ & $\begin{array}{c}\delta^{34} S_{\text {so4 }} \\
\text { (per mil) }\end{array}$ & $\begin{array}{c}\delta^{18} \mathbf{O}_{\mathrm{H} 20} \\
\text { (per mil) }\end{array}$ & $\begin{array}{c}\delta^{2} \mathrm{H}_{\mathrm{H} 20} \\
\text { (per mil) }\end{array}$ \\
\hline IC South-12 & 5.5 & 756 & 104 & 4.7 & nd & nd & -4.65 & -28.40 \\
\hline IC South-13 & 3.8 & 786 & 116 & 6.0 & 21.5 & 69.5 & -3.96 & -21.53 \\
\hline IC South-14 & 5.8 & 829 & 134 & 6.5 & nd & 69.5 & -3.68 & -19.93 \\
\hline
\end{tabular}

